\title{
CONSTITUTIONAL EXCEPTIONALISM
}

\author{
Michele Goodwin* \\ Allison M. Whelan**
}

Exceptionalism is the perception that a country, society, institution, movement, or time period is "exceptional" (i.e., unusual or extraordinary) in some way and thus does not need to conform to normal rules or general principles.

In recent years, a problematic trend has emerged: religion being used to justify harming women, people of color, member of the $L G B T Q$ community, and even inflicting injury on children. Such cases are escalating. Frequently, those who wish to impose harms on others in the name of religion claim an exception by statute or the constitution to do so. This Article argues that the use of religion to inflict injury or harm on others is a form of impermissible discrimination. Disturbingly, judicial deference to religiously based discrimination misreads free exercise of religion and expands the doctrine beyond its reasonable and legitimate limits. This Article selects sexbased bias as an example because religiously based discrimination targeting sex and gender reveals hostility to the concerns of women as a broad class, including all women with the potential to become pregnant, nonmarried pregnant women, members of the LGBTQ community, and transgendered females.

Our thesis is that religiously based discrimination targeting sex penalizes pregnant and contraceptive-seeking women for their status, carving out unconstitutional distinctions between men and women. Such bias undermines women's constitutional rights to be treated as equal citizens, secure in their bodies. We argue that the Free Exercise Clause of the First Amendment neither creates an "exception" nor grants a right to impose harmful conditions and injuries on others, including women.

* Chancellor's Professor, University of California, Irvine School of Law. Professor Goodwin holds appointments in the Departments of Criminology, Law, \& Society; Gender \& Sexuality Studies; and the Program in Public Health. She is the Director of the Center for Biotechnology \& Global Health Policy at UCI. Special thanks to Professor Robin Fretwell Wilson and editors at the Illinois Law Review.

** Law Clerk on the Second Circuit Court of Appeals (2016-2017); Former Senior Fellow, Center for Biotechnology \& Global Health Policy (2015). She received her J.D. from the University of Minnesota Law School (2014) and her Master of Arts in Bioethics from the University of Minnesota (2015). The views expressed in this article are the author's and do not represent those of any past, current, or future employer. She thanks Professor June Carbone and the editors of the Illinois Law Review. 
TABLE OF CONTENTS

I. INTRODUCTION 1288

II. MEDICAL REFUSALS HARM WOMEN AND IMPOSE UNDUE BURDENS ON ESTABLISHED REPRODUCTIVE RIGHTS.............. 1294

A. The Misuse of Science: The Contraceptive Context............. 1295

B. Constitutional Exceptionalism in the Emergency

Contraceptive Context 1301

1. Lori Boyer's Denial of Emergency Contraception After Rape 1302

2. Tara Harnish: Refused Emergency Contraception After Rape

3. Amanda Renz: Spurned at K-Mart 1303

4. Married and Refused Emergency Contraception, and Other Chilling Narratives

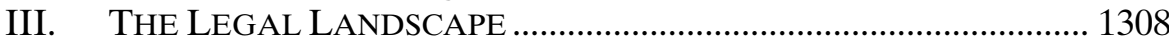

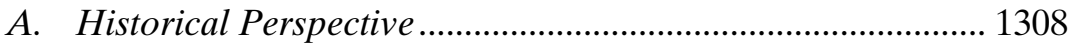

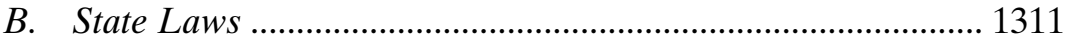

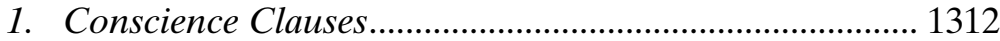

2. Religious Freedom Restoration Acts................................. 1313

3. Child-Abuse Statutes .......................................................... 1314

C. Federal Laws and the Religious Freedom Restoration

Act of 1993

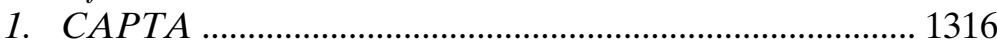

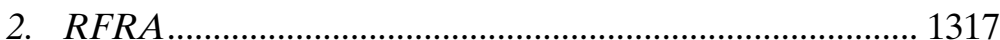

IV. RELIGION AS A TOOL FOR DISCRIMINATION............................... 1321

A. Statutory Claims.................................................................... 1322

1. Pharmaceutical Context .................................................... 1322

2. Abortion .............................................................................. 1324

B. The Hobby Lobby Problem ................................................ 1327

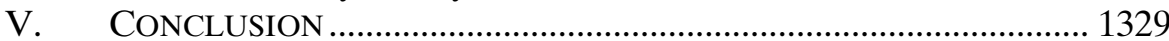

\section{INTRODUCTION}

In recent years, a problematic trend has emerged: religion being used to justify harming women, ${ }^{1}$ people of color, ${ }^{2}$ members of the

1. See Burwell v. Hobby Lobby Stores, Inc., 134 S. Ct. 2751, 2765 (2014) (featuring plaintiffs "seeking to enjoin application of ACA's contraceptive mandate" under the Religious Freedom Restoration Act and the Free Exercise Clause); see also Stormans, Inc. v. Wiesman, 794 F.3d 1064, 1084-85 (9th Cir. 2015) (upholding Washington statute requiring pharmacists to provide certain contraceptives against Free Exercise Clause challenge); Little Sisters of the Poor v. Burwell, 794 F.3d 1151 (10th Cir. 2015) (rejecting RFRA and Free Exercise Clause challenges to ACA's contraceptive requirement), cert. granted in part sub nom., S. Nazarene Univ. v. Burwell, 136 S. Ct. 446 (Nov. 6, 2015); Stormans, Inc. v. Selecky, 586 F.3d 1109, 1113 (9th Cir. 2009) (reversing injunction against rules proscribing pharmacists from withholding contraception from custmers and remanding for further proceedings on pharmacist's Free Exercise argument); Noesen v. Med. Staffing Network, Inc., 232 F. App'x 581, 584 (7th Cir. 2007) (rejecting Title VII argument of pharmacist fired for refusing to provide contraceptives due to religious beliefs). 
LGBTQ community, ${ }^{3}$ and even inflicting injury on children. ${ }^{4}$ Frequently, those who wish to (or do) impose harms on others in the name of religion claim an exception by statute ${ }^{5}$ or the Constitution to do so. That is, in some way, these individuals and groups believe that they do not need to conform to general principles and laws of nondiscrimination and accommodation in the United States. From time to time, courts condone this type of "exceptional" conduct, ${ }^{6}$ other times it is rejected, ${ }^{7}$ creating a

2. See, e.g., Alon Harish, Mississippi Church Refuses to Marry Black Couple, ABC News, (July 28, 2012), http://abcnews.go.com/US/mississippi-church-rejects-black-wedding/story?id=16878536; John Holland, Pastor Won't Wed Interracial Couple, Sun-SENTINEL (July 11, 2000), http://articles.sunsentinel.com/2000-07-11/news/0007110116_1_bumgardner-s-brother-wedding-nondenominationalchurch; Interracial Couple Spurned, ABC News, http://abcnews.go.com/US/story?id=96577\&page=1 (last visited Jan. 30, 2016); Kunbi Tinuoye, Kentucky Church Denies Racism After Vote to Ban Interracial Couples, THE GRIO (Dec. 1, 2011, 1:11 PM), http://thegrio.com/2011/12/01/kentucky-church-deniesracism-ban-interracial-couples.

3. See, e.g., Craig v. Masterpiece Cakeshop, Inc., No. 14CA1351, 2015 WL 4760453, at *21 (Colo. App. Aug. 13, 2015) (rejecting the Free Exercise argument of baker refusing customers due to religious views against same-sex marriage); Goodridge v. Dep't of Pub. Health, 798 N.2d 941, 1000 n.29, (Mass. 2003) (holding, inter alia, application of religious marriage's gender requirements to civil marriage irrational under state Due Process and Equal Protection clauses); Elane Photography, LLC v. Willock, 2013-NMSC-040, 309 P.3d 53, 77 (N.M. 2013) (rejecting photographer's Free Exercise argument for rejecting same-sex customers); (Aleksander Chan, Alabama Chief Justice Orders Judges to Refuse Gay Marriage Licenses, GAWKER (Feb. 9, 2015, 8:55 AM), http://gawker.com/alabama-chiefjustice-orders-judges-to-refuse-gay-marri-1684641625; James Higdon et al., Kentucky Clerk Ordered to Court After Refusing to Issue Gay-Marriage Licenses, WASH. POST (Sept. 1, 2015), https://www.wash ingtonpost.com/news/post-nation/wp/2015/09/01/will-kentucky-clerk-kim-davis-issue-gay-marriage-li censes-after-supreme-court-ruling; Taylor Wofford, Magistrates in a North Carolina County Refuse to Perform Same-Sex Marriages, NEws WeEK (Sept. 10, 2015, 3:25 PM), http://www.newsweek.com/north carolinajudgesrecusesamesexmarriage-370971.

4. See, e.g., Workman v. Mingo Cnty. Bd. of Educ., 419 Fed. App'x 348, 355 (4th Cir. 2011) (rejecting mother's claim that her religious beliefs against vaccinating her child as required by state law trigger the Equal Protection Clause); Boone v. Boozman, 217 F. Supp. 2d 938 (E.D. Ark. 2002) (featuring constitutional challenge to Arkansas' Child Immunization statute as applied to religiouslyopposed parent); Walker v. Super. Ct., 763 P.2d 852, 866 (Cal. 1988) (holding prayer-treatment exception to child neglect statutes inapplicable to involuntary manslaughter and felony child endangerment charges); State v. Neumann, 2013 WI 58, 348 Wis. 2d 455, 832 N.W.2d 560 (Wis. 2013) (holding, inter alia, treatment-through-prayer defense to child abuse statute inapplicable to reckless homicide).

5. Religious Exemptions to Child Neglect, NAT'L D. ATT'Ys Ass'N, http://www.ndaa.org/pdf/211-2015\%20Religious\%20Exemptions\%20to\%20Child\%20Neglect.pdf (last updated Feb. 2015) (discussing that thirty-nine states have laws exempting parents or guardians from criminal liability for failure to provide medical assistance to their children on the basis of religious beliefs); Aleksandra Sandstorm, Nearly All States Allow Religious Exemptions for Vaccinations, PEW Res. CENTER (July 16, 2015), http://www.pewresearch.org/fact-tank/2015/07/16/nearly-all-states-allow-religious-exemptionsfor-vaccinations (noting only California, West Virginia, Mississippi, and Minnesota lack religious exemptions to vaccination requirements); see also ARK. CODE ANN. § 5-10-101(9)(B) (2015) (providing religious defense to capital murder); IDAHO CODE ANN. § 18-1501(4) (2015) (providing religious defense to criminal injury to children); IOWA CODE $\$ 726.6$ (2016) (providing religious defense to felony child endangerment); LA. REV. STAT. ANN. § 14:93(3)(B) (2015) (providing religious defense to criminal neglect); Miss. CODE. ANN. § 43-21-105(I)(i) (2015) (providing religious defense to child neglect); OHIO REv. CODE ANN. § 2919.22(a) (West 2015) (providing religious defense to child neglect); OR. REV. STAT. § 163.115 (2013) (providing religious defense to homicide of child); W. VA. CODE § 61-8D2(d) (2015) (providing religious defense to murder of child).

6. Hobby Lobby, $134 \mathrm{~S}$. Ct. at 2785 (holding the ACA's contraception mandate contrary to RFRA as applied to closely held corporations).

7. Davis v. Miller, 136 S. Ct. 23 (2015) (denying petitioner's stay of an injunction that bans her from refusing to issue marriage licenses to gay couples); see Miller v. Davis, No. 15-5880 (6th Cir. Aug. 26,2015 ) (holding, "[i]n light of the binding holding of Obergefell, it cannot be defensibly argued that the holder of the Rowan County Clerk's office, apart from who personally occupies that office, may decline to act in conformity with the United States Constitution as interpreted by a dispositive holding 
mishmash of law and contradictions within the broader canon of antidiscrimination law.

Individuals who desire to turn away gay men and women from purchasing wedding supplies, ${ }^{8}$ clerks who refuse to issue marriage licenses to interracial or gay couples, ${ }^{9}$ doctors who deny medical care to children of gay couples,$^{10}$ or parents who claim a religious right to pray rather than provide healthcare to their children ${ }^{11}$ believe that the First Amendment's Free Exercise Clause tolerates these forms of discrimination and harms. Some people have claimed that the Free Exercise Clause grants a fundamental right to cause harm to others. In some instances, those claiming religious constitutional protections for their actions work for the government.

For example, in a recent case, a county clerk in Kentucky refused to issue marriage licenses to gay couples even after the U.S. Supreme Court ruling in Obergefell $v$. Hodges, which legalized gay marriage. ${ }^{12}$ Her attorney issued a statement noting that Ms. Kim Davis, an Apostolic Christian, "holds an undisputed sincerely held religious belief that marriage is a union between a man and a woman only." ${ }^{13}$ In that religious-refusal case, the clerk maintained her defiance (and job) despite the fact that the Supreme Court denied her petition to reject gay applicants from receiving marriage licenses. ${ }^{14}$ She issued a statement explaining, "I . . . am re-

of the United States Supreme Court"); see also Plaintiff's Motion to Hold Defendant Kim Davis in Contempt of Court, Miller v. Davis, No. 0:15-cv-44-DLB, 2015 WL 7348754 (E.D. Ky. 2015) (motion to hold defendant Kim Davis in contempt).

8. Sarah Larimer, Colorado Court Sides Against Baker Who Cited Religious Beliefs, Refused Same-Sex Marriage Cake Order, WASH. Post (Aug. 13, 2015), http://www.washingtonpost.com/ news/acts-of-faith/wp/2015/08/13/colorado-court-sides-against-baker-who-cited-religious-beliefsrefused-same-sex-couple ("Phillips cited his Christian beliefs as justification for the decision, and contended that creating the cake would violate his right to free speech, as well as his religious freedom.”).

9. A North Carolina law permits magistrates and clerks to reject issuing licenses and marrying any couple it finds objectionable to their sincerely held religious beliefs. See Mark Joseph Stern, North Carolina May Soon Let Clerks Refuse Marriage Licenses to Gay and Interracial Couples, SLATE (June 2, 2015 2:39 PM), http://www.slate.com/blogs/outward/2015/06/02/north_carolina_law_lets_magistrates _refuse_marriage_licenses_to_gay_and.html.

10. Abby Phillip, Pediatrician Refuses to Treat Baby with Lesbian Parents and There's Nothing Illegal About It, WASH. POST (Feb. 19, 2015), http://www.washingtonpost.com/news/morning-mix/ $\mathrm{wp} / 2015 / 02 / 19 /$ pediatrician-refuses-to-treat-baby-with-lesbian-parents-and-theres-nothing-illegalabout-it.

11. Caroline Fraser, Suffering Children and the Christian Science Church, ATL. MONTHLY (Apr. 1995), http://www.theatlantic.com/past/docs/unbound/flashbks/xsci/suffer.htm.Tamara Jones, Prayers, Parental Duty: Child Deaths Put Faith on Trial, L.A. TIMEs (June 27, 1989), http://articles.latimes.com/ 1989-06-27/news/mn-4359_1_christian-science-child-abuse-parents (noting that in the five years before the article's publication, "seven cases ... have come under public scrutiny").

12. 135 S. Ct. 2584, 2607 (2015); Pete Williams, Supreme Court Rules Against Kentucky Clerk in Gay Marriage Case, NBC News.cOM (Sept. 1, 2015, 8:03 AM), http://www.nbcnews.com/news/usnews/supreme-court-rules-against-kentucky-clerk-gay-marriage-case-n419191.

13. See Williams, supra note 12.

14. Sarah Kaplan \& James Higdon, The Defiant Kim Davis, the Ky. Clerk Who Refuses to Issue Gay Marriage Licenses, WASH. POST (Sept. 2, 2015), http://www.washingtonpost.com/news/morning$\mathrm{mix} / \mathrm{wp} / 2015 / 09 / 02 /$ meet-kim-davis-the-ky-clerk-who-defying-the-supreme-court-refuses-to-issue-gaymarriage-licenses. 
questing what our Founders envisioned-that conscience and religious freedom would be protected." 15

In Alabama, the Chief Justice, Roy Moore, defied the U.S. Supreme Court after it struck down gay-marriage bans. Moore told judges, "no (probate judge) has to issue a marriage license to a same sex couple," for twenty-five days. ${ }^{16}$ Moore's decree may have been more symbolic than valid $^{17}$-but the message was clear. Moore compared magistrates conducting gay marriages to committing Nuremberg war crimes: "say that I was following the orders of the highest authority to kill Jews . . Could I say I was ordered to do so?" 18 When pushed by a reporter on the absurdity of the comparison, the Chief Justice responded, "[i]s there a difference?" 19

In North Carolina, more than a dozen magistrates officially refused to perform gay marriages by recusing themselves..$^{20}$ The magistrates cited a "sincerely held religious objection." ${ }^{21}$ In other words, private citizens as well as government employees, and even judges, may hold irrational beliefs that the Free Exercise Clause grants a right or exception to inflict injury on others, particularly if their religious beliefs are "sincere." 22

The Supreme Court attempted to address this concern, at least within the context of gay marriage, in Obergefell. In that case, the Court reasoned that "the Constitution... does not permit the State to bar samesex couples from marriage on the same terms as accorded to couples of the opposite sex," despite "sincere conviction[s]" in their religious beliefs..$^{23}$ The Court made clear in its ruling, just as we emphasize here, that "those who adhere to religious doctrines, may continue to advocate with utmost, sincere conviction that ... same-sex marriage should not be condoned." ${ }^{24}$ In fact, people may hold whatever religious views they desire. The right, however, to hold beliefs, even discriminatory convictions, is

15. Id. (quoting Kim Davis).

16. Charles J. Dean, Roy Moore: Alabama Judges Not Required to Issue Same-Sex Marriage Licenses for 25 Days, AL.COM (Jan. 6, 2016, 1:31 PM) (emphasis omitted), http://www.al.com/news/ index.ssf/2015/06/roy_moore_gay_marriage.html. In this case, Justice Moore claimed that gay marriage was inconsistent with Alabama's constitution. This may have been cover or obfuscation for religious beliefs as Moore is quoted saying that marriage and the "pursuit of happiness is given by God under our law." Charles J. Dean, Alabama Chief Justice Moore: Gay Marriage "Not in Accordance with Constitution,” AL.COM (June 30, 2015, 8:34 PM), http://www.al.com/news/index.ssf/2015/06/alabama _chief_justice_moore_ga.html.

17. Shannon Minter of the National Center for Lesbian Rights stated that Moore's order had "'no practical effect," because a federal judge ordered Alabama judges to ignore the state's marriage ban in the wake of Obergefell. Dean, Roy Moore: Alabama Judges not Required to Issue Same-Sex Marriage Licenses for 25 Days, supra note 16.

18. Dean, Alabama Chief Justice Moore: Gay Marriage "Not in Accordance with Constitution," supra note 16.

19. $I d$.

20. 14 NC Magistrates Use Recusal Law Focusing on Gay Marriage, WSOCTV.COM (July 8, 2015, 5:15 AM), http://www.wsoctv.com/news/news/local/14-nc-magistrates-use-recusal-law-focusinggay-mar/nmtHg.

21. Id.

22. See Williams, supra note 12.

23. Obergefell v. Hodges, $135 \mathrm{~S}$. Ct. at 2607.

24. Id. 
quite distinct from expecting the law to condone the infliction of injuries on others or to grant a right to do so.

Despite the landmark ruling in Obergefell, the Supreme Court has not always been clear or consistent in its anti-discrimination approach when it comes to religion-and neither has Congress or state legislatures. For instance, consider Burwell v. Hobby Lobby. ${ }^{25}$ At issue in that case was whether the Religious Freedom Restoration Act of $1993^{26}$ ("RFRA") permitted the U.S. Department of Health and Human Services ("HHS") to require "closely held corporations" to provide their employees with health insurance coverage for contraceptives that violate the corporation owners' sincerely held religious beliefs. ${ }^{27}$ In a sharply divided 5-4 opinion written by Justice Alito, the Court held that "[a]s applied to closely held corporations, the HHS regulations imposing the contraceptive mandate violate RFRA." ${ }^{28}$

The Supreme Court's ruling in Burwell v. Hobby Lobby resurfaces important questions related to reproductive rights. Does the U.S. Constitution's recognition of religious rights infer a hierarchy among rights? Are religious interests among groups and individuals so vitally distinct that their protection permits discrimination against all other citizens? Are religious protections or rights under the U.S. Constitution absolute? Despite the flurry of news articles published in the wake of the Court's Hobby Lobby ruling, legal scholarship on these and related questions remains surprisingly thin.

Further, the confusing judicial record on this matter is obvious. On one hand, the Supreme Court recently rejected a county clerk's insistence that her religious beliefs provide her a right to discriminate against gay men and women in her employment capacities. On the other hand, the Court has reasoned that corporations may have religious beliefs and freely exercise their religion to injure female employees even if their conduct violates Congressional mandates.

This Article examines constitutional exceptionalism's legal blind spot. That is, under the premise of protecting religious groups, some legislatures and courts have granted individuals and groups authority to inflict dignitary, and even physical, harms on others. ${ }^{29}$ In Hobby Lobby,

25. 134 S. Ct. 2751 (2014)

26. 42 U.S.C. $\$ \$ 2000 b b-4(2012)$.

27. Hobby Lobby, 134 S. Ct. at 2759.

28. Id. at 2785 (emphasis added).

29. See, e.g., id.; ALA. CODE § 13A-13-6 (2015) (providing religious exemption to endangering the welfare of a child when parents use religious practices in lieu or medical treatment); GA. CODE ANN. § 49-5-180 (West 2015) ("No child who in good faith is being treated solely by spiritual means through prayer ... shall, for that reason alone, be considered to be an abused child."); 325 ILL. CoMP. STAT. 5/3 (2015) ("A child shall not be considered neglected or abused for the sole reason that such child's parent or other person responsible for his or her welfare depends upon spiritual means through prayer alone for the treatment or cure of disease ...."); IOWA CODE § 232.68(2)(4)(c) (2015) ("A parent or guardian legitimately practicing religious beliefs who does not provide specified medical treatment for a child for that reason alone shall not be considered abusing the child ...."); MO. REV. STAT. $\$ 210.115 .4$ (2015) (providing religious exemption to child abuse and to being entered in the state abuse registry where parents deny medical care on the basis of religious beliefs); MONT. CODE ANN. 
Justice Alito emphasized that federal law protecting religious freedom "applies to regulations that govern the activities of closely held for-profit corporations like Conestoga, Hobby Lobby, and Mardel." ${ }^{30}$ If that is so, what if the owners of Hobby Lobby refused to provide health insurance to same-sex spouses based on religious beliefs? Or refused to provide unique medical services essential to transgendered employees? Arguably, Hobby Lobby makes a strong case for supporting that type of discrimination.

This Article queries whether judicial deference to religiously based discrimination misreads free exercise of religion and expands the doctrine beyond its reasonable and legitimate limits. This Article selects sexbased bias as a case study because religiously based discrimination targeting sex and gender reveals hostility to the concerns of women as a broad class, including all women with the potential to become pregnant, nonmarried pregnant women, lesbians, and transgendered females.

This Article argues that the use of religion to inflict injury or harm on others is a form of impermissible discrimination. Specifically, religiously based or inspired discrimination targeting sex penalizes pregnant and contraceptive-seeking women for their status, carving out unconstitutional distinctions between men and women. Such bias undermines women's constitutional rights to be treated as equal citizens, secure in their bodies. We argue that the Free Exercise Clause does not create an exception nor does it grant a right to impose harmful conditions and injuries on others, including women.

This Article develops in three parts. Part II takes up our claim that unrestrained religious exemptions in the reproductive context interferes with reproductive liberty and entrenches discriminatory norms. This Part demonstrates how women suffer harms in the name of religion. Part III turns to the law governing free exercise of religion, describing and highlighting the incoherence of law that dominates this domain. Part IV considers what weight and deference should be granted to individuals, groups, and corporations that seek to discriminate based on religion. It argues that there is no constitutional right rooted in free exercise that grants a right to discriminate, injure, or harm others.

\$ 41-3-102. (2015) (denying medical care for religious reasons does not constitute child abuse); N.H. REV. STAT. ANN. § 639:3 (2015) ("A person who pursuant to the tenets of a recognized religion fails to conform to an otherwise existing duty of care or protection is not guilty of an offense under this section.”); N.J. STAT. ANN. § 9:6-8.21 (West 2015) (providing religious exemption from child abuse in treatment by spiritual means); 23 PA. CONS. STAT. $§$ 6304(b) (2014) (providing that failure to provide medical treatment to child for religious reasons does not constitute child abuse); R.I. GEN. LAWS § 119-5 (2015) (providing that failure to provide medical care to child for religious reasons does not constitute child abuse); TENN. CODE ANN. § 39-15-402 (West 2015) (providing that denial of medical care for religious reasons is not child abuse in and of itself); UTAH CODE ANN. § 76-5-109 (Lexis Nexis 2015) (providing that there is no offense of child abuse where parents withhold necessary medical treatment from their children for religious reasons); VA. CODE ANN. § 63.2-100(2) (2015) (providing that there is no criminal offense where parent withholds medical treatment from child for religious reasons).

30. Hobby Lobby, 134 S. Ct. at 2775. 


\section{MedicAl Refusals HaRm Women AND IMPOSE Undue BURDENS ON ESTABLISHED REPRODUCTIVE RIGHTS}

Cases across the U.S. illustrate how physicians, hospital staff, and even pharmacists believe they have a right to refuse to provide medical services to their female patients, even in emergency situations where the patients suffer injuries or may die. According to Adam Sonfield of the Guttmacher Institute, "[t]here are pharmacists who will only give birthcontrol pills to a woman if she is married." ${ }^{11}$ In fact, "[t]here are pharmacists who mistakenly believe contraception is a form of abortion and refuse to [dispense] to anyone ... [and] there are even cases of pharmacists holding prescriptions hostage, where they won't even transfer it to another pharmacy when time is of the essence." ${ }^{32}$ The scale and scope of this problem may be difficult to measure; however, cases in California, Georgia, Washington, Louisiana, Illinois, Massachusetts, Texas, Ohio, New Hampshire, Wisconsin, North Carolina, and Pennsylvania where women have been denied emergency contraceptives indicate a troubling trend. ${ }^{33}$

Sometimes medical providers wish to only provide the services tolerable to their personal religious beliefs or the doctrines or teachings of their religious leaders. In other work, such issues are taken up with regard to parents refusing to provide medical care to their children, choosing instead to defer to their religious tenets, ideologies, and beliefs even when doing so will inflict injuries and death on their children. ${ }^{34}$

This is no small issue, as Steven H. Aden of the Christian Legal Society's Center for Law and Religious Freedom explained to the Washington Post, emphasizing that "this is a very big issue that's just beginning to surface." ${ }^{35}$ Aden noted that "[m]ore and more pharmacists are becoming aware of their right to conscientiously refuse to pass objectionable medications across the counter," predicting that "[w]e are on the very front edge of a wave that's going to break not too far down the line." 36

As discussed in Part III, states sometimes accommodate this behavior under the guise of protecting religious freedom. Substantively, however, state deference to religious exceptions and exemptions in women's reproductive medical care reveal hostility to women's healthcare, particularly that of low-income women and those living in rural areas where medical providers and institutions may be limited. The cases described below call attention to painful realities for women patients: obtaining appropriate reproductive care may not be guaranteed in their local

31. Rob Stein, Pharmacists' Rights at Front of New Debate: Because of Beliefs, Some Refuse to Fill Birth Control Prescriptions, WASH. POST, Mar. 28, 2005, at A1, available at http://www.washington post.com/wp-dyn/articles/A5490-2005Mar27.html.

32. Id. (quoting Sonfield).

33. Id.

34. Erwin Chemerinsky \& Michele Goodwin, Religion is Not a Basis for Harming Others, 104 GEO. L.J. 1111, 1113-16 (2016).

35. Stein, supra note 31

36. Id. 
communities. Moreover, the cases are particularly illustrative of a trend that extends beyond specific geographic regions in the U.S.

Part II provides descriptive accounts of the harms and injuries women have suffered as a result. In addition, it specifically highlights the misuse of science generally in the reproductive contexts.

\section{A. The Misuse of Science: The Contraceptive Context}

"President Obama, in a stunning, shocking level of power, now just recently told all private insurance companies, 'You must offer the morning-after abortion pill, because I said so. And it must be free of charge.' That same level coming through executive orders and through government dictates is wrong." 37

—former Minnesota Rep. Michele Bachmann (2011)

"These medications are there to prevent or delay ovulation ... they don't act after fertilization."

Many of the entanglements about women's legal rights in the reproductive context relate to science. Concerns over fetal health and wellbeing dominate political discourse about reproduction. Politicians speak with authority on issues that news media and the public take for granted as truthful and reliable. Rarely is the science challenged, particularly within the legal discourse. Sometimes, however, that which is purported to be "science" is misused or misunderstood. At other times, blatant falsehoods regarding contraception and abortion dominate political discourse, shaping media coverage, public understanding, and ultimately law. For example, few would know that legal abortions are safer for women than carrying pregnancies to term. Research shows that a woman is fourteen times more likely to die during her pregnancy and childbirth than when having an abortion. ${ }^{39}$

One glaring example of myth persuasively substituting for science is found in the confusion between contraception and abortifacients. Subpart A addresses emergency contraception in light of recent Supreme Court discourse in Hobby Lobby as a potent, but also representative ex-

37. Are Health Plans Forced to Cover Free 'Abortion Pills?', CNN (Sept. 13, 2011 12:54 PM), http://www.cnn.com/2011/POLITICS/09/13/truth.squad.contraception (quoting Congresswoman Michele Bachmann).

38. Pam Belluck, Abortion Qualms on Morning-After Pill may be Unfounded, N.Y. TIMES (June 5, 2012), http://www.nytimes.com/2012/06/06/health/research/morning-after-pills-dont-block-implan tation-science-suggests.html (quoting Dr. Casey of the Mayo Clinic and noting that, "[b]ased on the belief that a fertilized egg is a person, some religious groups and conservative politicians say disrupting a fertilized egg's ability to attach to the uterus is abortion.").

39. E.G. Raymond \& D.A. Grimes, The Comparative Safety of Legal Induced Abortion and Childbirth in the United States, 119 OBsteTRICs \& GyNECOLOGY 215, 215-19 (Feb. 2012), available at http://www.ncbi.nlm.nih.gov/pubmed/22270271. 
ample of the coercive use of religion as well as the misrepresentation of science. Abortion is another key example addressed in other work. ${ }^{40}$

In Hobby Lobby, its owners claimed religious opposition to abortion. The subject of their lawsuit, however, was the Patient Protection and Affordable Care Act's ("ACA") federal contraception mandates. The difference is important. Contraceptives prevent pregnancies. Abortifacients terminate pregnancies. The drugs and procedures function distinctly and differently. ${ }^{41}$ By definition and how they function as described below, contraceptives are not abortifacients, because they prevent pregnancies from occurring. A logical comparative would be vaccines. Vaccines function to prevent diseases and illnesses. A vaccine, however, is not an antibiotic or medication to be used after the illness has imbedded in the body. For example, abortifacients work only to terminate pregnancies; they cannot prevent a pregnancy from establishing in a woman's uterus. So, why does this matter?

Increasingly, pharmacists refuse to dispense or prescribe birth control and emergency contraception ("EC"), citing religious or moral objections. Pharmacists ground their justifications based on the belief that such hormonal contraceptives, particularly emergency contraception, cloak the true purpose of that medicine, which is to abort or destroy a fertilized egg. ${ }^{42}$ This belief persists and is used to sway judges, legislators, and the public despite significant evidence that emergency contraception prevents pregnancy primarily, if not exclusively, by delaying or inhibiting ovulation rather than destroying an already-fertilized egg. ${ }^{43}$ In reading hundreds of political statements and articles quoting politicians, it is clear that many lawmakers responsible for crafting legislation that impacts women's lives lack basic awareness and understanding of women's health and reproduction: ovulation, fertilization, and pregnancy. For too many, these are all blurred lines. ${ }^{44}$

40. See Michele Goodwin, Constitutional Exceptionalism and the Abortion Context (on file with author).

41. There are two types of emergency contraceptives available in the U.S.: emergency contraceptive pills such as Plan B and Ella and the copper intrauterine device ("IUD"). Frequently Asked Questions, Contraception, AM. C. OBSTETRICIANS \& GYNECOLOGISTS (Oct. 2013), http://www.acog.org//media/For-Patients/faq114.pdf?dmc=1\&ts=20150907T1821589791 [hereinafter ACOG Fact Sheet].

42. Mary K. Collins, Conscience Clauses and Oral Contraceptives: Conscientious Objection or Calculated Obstruction?, 15 Annals Health L. 37, 37 (2006).

43. See Gabriela Noe et al., Contraceptive Efficacy of Emergency Contraception with Levonorgestrel Given Before or After Ovulation, 81 CONTRACEPTION 486, 492 (2010) (concluding that levonorgestrel is "highly effective for preventing unintended pregnancy when it is used before ovulation, but when used after ovulation, it is completely unable to prevent pregnancy because it had no effect on subsequent reproductive processes ...." (emphasis added)); Natalia Novikova et al., Effectiveness of Levonorgestrel Emergency Contraception Giving Before or After Ovulation-A Pilot Study, 75 CONTRACEPTION 112, 117 (2007).

44. Amanda Marcotte, Idaho Lawmaker Who Doesn't Understand Female Anatomy Knows What's Good for Women, SLATE (Feb. 24, 2015), http://www.slate.com/blogs/xx_factor/2015/02/24/ vito_barbieri_anti_abortion_idaho_republican_asks_if_you_can_reach_the_vagina.html (reporting on Idaho lawmaker who queried whether gynecological exams could be performed by a woman swallowing a camera). 
Thus, the controversy surrounding how one defines contraceptives may not be surprising given political misinformation about the definition of a pregnancy. The scope of this problem is significant. According to the Center for Reproductive Rights, "every 10.5 seconds an unplanned pregnancy occurs in the U.S." ${ }^{45}$ This results in about three million unplanned pregnancies per year. ${ }^{46}$ Not all of these pregnancies will end in births; about 1.29 million will terminate in abortions. ${ }^{47}$ Over the span of a decade this could mean thirty million unintended pregnancies and almost thirteen million abortions. Emergency contraceptives can play a significant role by considerably reducing the number of unplanned pregnancies-if women have access. Thus, how politicians label these drugs can significantly impact women's lives.

The scientific community and federal law have long defined a pregnancy by the status of a fertilized egg implanted in the wall of a woman's uterus. ${ }^{48}$ That is, pregnancy begins when a fertilized egg is implanted in the uterus. Conception is an essential step toward pregnancy, but a fertilized egg is not a pregnancy. Rather, conception is a fertilized egg in need of a home in the uterine wall-without that, a woman's body will terminate it during her monthly menstrual cycle. ${ }^{49}$ The basic laws of biology dictate that not only will a pregnancy not develop from a hovering fertilized egg, it cannot develop without implantation. ${ }^{50}$

How pregnancy is defined becomes "critical to distinguishing between a contraceptive that prevents pregnancy and an abortifacient that terminates it." ${ }^{51}$ Nevertheless, state definitions of pregnancies vary and the sharp divide as to what a pregnancy is impacts law and ultimately women's healthcare and medical access. As noted by the Guttmacher Institute in a 2005 report, some states define a pregnancy at the point of "conception," 52 which is scientifically imprecise and misleading.

These facts matter for law because policies, legislation, and judicial opinions derive from these understandings. Moreover, because appointments to federal agencies, such as the Food and Drug Administration ("FDA") can be and have been politicized in the reproductive context, safe contraceptives can be delayed coming onto the market or inaccu-

45. Press Release, Ctr. for Reproductive Rights, Center for Reproductive Rights Questions Timing of FDA Plan B Announcement (July 31, 2006), http://www.reproductiverights.org/pressroom/center-for-reproductive-rights-questions-timing-of-fda-plan-b-announcement.

46. Id.

47. Id.

48. Allen J. Wilcox et al., Time of Implantation of the Conceptus and Loss of Pregnancy, 340 New ENG. J. MED. 1796 (1999), available at http://www.nejm.org/doi/full/10.1056/NEJM19990 6103402304.

49. Id. at 1799

50. The rare exception is an ectopic pregnancy that develops in the fallopian tubes. Such pregnancies are incredibly rare, and when they do occur, they threaten the woman's life.

51. Rachel Benson Gold, The Implications of Defining When a Woman is Pregnant, 8 GUTTMACHER REP. PUB. POL'Y 7 (May 2005), available at https://www.guttmacher.org/pubs/tgr/ 08/2/gr080207.html.

52. Id. at 8 . 
rately labeled in the process..$^{53}$ In 2009, U.S. District Court Judge Edward $\mathrm{R}$. Korman ruled that the FDA ignored science while allowing politics to dictate its decisions in 2006 to limit access to over-the-counter emergency contraceptives to women over the age of eighteen. In a scathing opinion, he wrote, "[t $\mid$ he FDA repeatedly and unreasonably delayed issuing a decision on Plan B for suspect reasons." ${ }_{54}$

The opinion went on to say:

Putting aside for the moment the specifics of the many claims brought by plaintiffs and the details of each of the FDA's decisions, the gravamen of plaintiffs' claims is that the FDA's decisions regarding Plan B-on the Citizen Petition and the SNDAs-were arbitrary and capricious because they were not the result of reasoned and good faith agency decision-making ... Plaintiffs are right. ${ }^{55}$

If politicians confuse contraceptives with abortifacients this may very likely impact legislation, which in turn affects access to preventative pregnancy medicines that have nothing to do with aborting a fetus-or even impairing fertilized ova-as was demonstrated during the Bush Administration. ${ }^{56}$ Neglecting or overruling science in favor of a religious agenda that misreads biology could also have devastating, chilling impacts on the choices women make, including for "pro-life" women who oppose abortion. For example, women who oppose abortion, but who do not wish to be pregnant, might sidestep using this very relevant medical option based on misleading, inaccurate information. ${ }^{57}$

If emergency contraceptives are not abortifacients, how do they work? There are three types of emergency contraceptive pills and the copper intra-uterine device ("IUD"). ${ }^{58}$ Some are available over the coun-

53. Irin Carmon, The Myth of the "Morning After Abortion Pill," SALON (Apr. 26, 2012), http://www.salon.com/2012/04/26/the_myth_of_the_morning_after_abortion_pill (arguing that "there's a reason why people mistake emergency contraception and abortion: The right intentionally confuses the two.").

54. Tummino v. Torti, 603 F. Supp. 2d 519, 523 (E.D.N.Y. 2009) amended sub nom. Tummino v. Hamburg, Nos. 05-CV-366 (ERK)(VVP), 12-CV-763 (ERK)(VVP), 2013 WL 865851 (E.D.N.Y. Mar. 6, 2013).

55. Id.

56. Press Release, Ctr. for Reproductive Rights, Depositions Indicate Bush Administration Exerted Political Influence on FDA During Plan B Review Process (Aug. 30, 2006), available at http://www.reproductiverights.org/press-room/depositions-indicate-bush-administration-exerted-politi cal-influence-on-fda-during-plan-b (noting that depositions released in the Center for Reproductive Rights lawsuit against the FDA "indicate that the Bush Administration sought to unduly influence the agency during the Plan B application review process.").

57. Examining the vast number of unintended pregnancies could shed light on how misinformation may chill women's reproductive decision-making. For example, twenty-five years ago, researchers predicted widespread use of emergency contraceptives would significantly reduce unintended pregnancies. Those researchers, however, now say that many women avoid or choose not to use emergency contraceptives after unprotected sex-even though access is now available. Further research might help to explain why, including teasing out whether women's decision-making has been influenced by political rhetoric and misinformation. Richard Knox, Plan B Ruling Reveals Glimpse into Bush's FDA, NPR (Mar. 24, 2009), http://www.npr.org/templates/story/story.php?storyId $=102294234$.

58. The three types of emergency contraceptive pills are: ulipristal, progestin (only), and combination pills. The IUD is a small medical device inserted into the uterus where it remains to prevent pregnancies. See ACOG Fact Sheet, supra note 41. The IUD is also used as a long-acting reversible 
ter and others through prescription or surgical insertion, in the case of the IUD. ${ }^{59}$ Emergency contraceptives function to minimize or eliminate the risk of unplanned pregnancy in two different ways. First, they work to slow ovulation, which is the release of ova from the ovaries. ${ }^{60}$ If the ova are not present, a pregnancy cannot take place. Second, they thicken the cervical wall "so sperm have trouble swimming."

Because of scientific misunderstanding, some people, including politicians, confuse these contraceptives with killing a fetus. ${ }^{62}$ Former presidential candidate Mitt Romney referred to emergency contraceptives as "abortive pills" and other politicians "have made similar statements." ${ }^{63}$

Such political statements conflict with science: leading health authorities, including the National Institutes of Health, World Health Organization, the Cleveland Clinic, and the Mayo Clinic among others, emphasize that a pregnancy exists only after a fertilized egg is actually implanted in the uterus. Despite their clarity on the issue, some politicians continue to claim that to disrupt implantation is akin to abortion, or as the American Association of Pro-life Obstetricians and Gynecologists claim, it is the "moral equivalent of a homicide." ${ }^{64}$ To them, conception and fertilization are the equivalent of pregnancy.

Scientifically, however, conception is essentially fertilization-and not pregnancy. Understanding this finer point is important for law. According to the U.S. National Library of Medicine, "around half of all fertilized eggs die and are lost (aborted) spontaneously." ${ }^{65}$ In a recent study, Professor Jan Brosens likened the process of some fertilized eggs implanting and others not to an "entrance exam." ${ }^{66}$ In other words, fertilized eggs, or what some politicians might refer to as "conception eggs" simply fail to implant - a woman's uterus basically rejects them. Reasons for the failure vary, including the quality of a woman's ova, chromosomal abnormalities in the embryo, the woman's age, and the fact that pregnancies generally are considered parasitic. ${ }^{67}$ Even among women who become pregnant, their bodies will attempt to reject those pregnancies, re-

contraceptive. See Peter Beldin, Cynthia C. Harper, and J. Joseph Speidel, The Copper IUD for Emergency Contraception, A Neglected Option, 85 CONTRACEPTION 338 (2012).

59. Plan B One Step, which is progestin-only can be purchased over the counter as well as Next Choice One Dose. Combination pills and Ulipristal require a medical prescription. See id.

60. Progestin-only pills function to prevent pregnancy by preventing ovulation. These pills do not work if a woman is already pregnant. It is worth noting that a mature "egg is fertilizable for only a short period of time (usually between 8 and 12 hours) 6 Things to Know About Conception, Nat'l Inst. Health, http://www.nichd.nih.gov/news/resources/links/infographics/Documents/NICHD_InfoGraphic _Conception.pdf\#search=conception (last visited Jan. 31, 2016).

61. Belluck, supra note 38 .

62. See id.

63. $I d$.

64. Id. (quoting Dr. Donna Harrison, research director for the American Association of Pro-Life Obstetricians and Gynecologists).

65. MedlinePlus, Miscarriage, U.S. NAT’L LIBR. MED. (Nov. 16, 2014), https://www.nlm.nih.gov/ medlineplus/ency/article/001488.htm.

66. Rachel Rettner, Fate of a Fertilized Egg: Why Some Embryos Don't Implant, LIVESCIENCE (Feb. 6, 2014, 10:18 AM), http://www.livescience.com/43157-embryo-implant-signals-pregnancy.html.

67. Id. 
sulting in about fifteen to twenty percent of all pregnancies ending in miscarriage. ${ }^{68}$

Nevertheless, some politicians suggest that their religious views should be granted greater deference in courts and legislatures than peerreviewed science. In arguing against the ACA's contraceptives provision, former presidential candidate and longtime Congresswoman Michele Bachman told national audiences on $\mathrm{CNN}$ and other networks that emergency contraception causes abortion. ${ }^{69}$ She claimed that if the law passed, ten-year-old girls would pick up emergency contraceptives while on shopping trips. ${ }^{70}$ Notwithstanding the outlandishness of such punditry, news media may be slow to correct the inaccuracies.

For example, despite the fact that Congresswoman Bachmann's statement was erroneous, CNN ran a story referring to emergency contraceptives as "abortion pills" 11 in its headline. This too was scientifically inaccurate, and whether to draw in readers or not, the headline potentially framed how millions of people in the U.S. view emergency contraceptives.

The critical question then is whether emergency contraceptives can induce abortion and whether pharmacists would be justified in their concerns that the products are misbranded. Empirical evidence shows that emergency contraception has neither medical efficacy nor benefit for pregnant patients. ${ }^{72}$ This evidence raises questions about the validity and authoritative weight granted pharmacists' religious refusals to dispense emergency contraception because they believe it is equivalent to an abortion. In such cases, religion is deployed as a prophylactic shield to counter the dispensation of medical treatments that would seem not to interfere with religious beliefs.

Medical discrimination of that kind not only conflicts with the constitutional interests of women who seek such medical treatments, but also violates medical standards and broader ethical norms. According to the American College of Obstetricians and Gynecologists ("ACOG") Committee on Ethics, "provider refusals to dispense emergency contraception based on unsupported beliefs about its primary mechanism of action should not be justified." "ᄁ3 In a platform highlighting their concerns, ACOG elaborates that permissive religious discrimination in these contexts may disproportionately impact economically vulnerable women, explaining that "single, affluent [women] might experience such a refusal as inconvenient and seek out another physician, [however] a young

68. Catherine Pearson, Miscarriage Causes, Rates Widely Misunderstood, Study Shows, HUFFINGTON POST (Oct. 17, 2013 2:53 PM), available at http://www.huffingtonpost.com/2013/10/ 17/miscarriage-cause_n_4116712.html.

69. Are Health Plans Forced to Cover Free Abortion Pills?, CNN (Sept. 13, 2011), http://www. cnn.com/2011/POLITICS/09/13/truth.squad.contraception.

70. See id.

71. Id.

72. See supra note 43.

73. Comm. on Ethics, The Limits of Conscientious Refusal in Reproductive Medicine, AM. COLL. OBSTETRICIANS \& GYNECOLOGISTS COMM. OP. No. 385, 4 (2007) (reaffirmed 2016). 
mother of three depending on public transportation might find such a refusal to be an insurmountable barrier to medication because other options are not realistically available to her."

Such risks place an undue burden on women such that they lose control of their "reproductive fate and quality of life" impacting not only themselves, but also their children. ${ }^{75}$ ACOG persuasively argues, "[r] efusals that unduly burden the most vulnerable of society violate the core commitment to justice in the distribution of health resources." 76

Despite these and other disproportionately distributed burdens that result when healthcare providers or institutions claim a conscientious objection, courts have generally allowed pharmacists to refuse dispensing emergency contraception. ${ }^{77}$ The following cases further illustrate our concerns.

\section{B. Constitutional Exceptionalism in the Emergency Contraceptive Context}

As religious objections escalate, women suffer the consequences, as they continue to be harmed when state-licensed pharmacists refuse to dispense the medications that female patients have legal and medical rights to receive. In race contexts, such discrimination would no longer be tolerated, even if racial minorities could seek accommodations elsewhere. Sex discrimination of this kind is treated differently, however, in both society and law. The injuries caused by medical professionals who object to providing women medical care and services may be catalogued in numerous ways, including stigmatizing, shaming, inflicting emotional distress, and exposing them to physical harms, infections, unintended pregnancies, and even death. These injuries may be particularly acute when medications must be sought and obtained in a timely manner in order for the drugs to be most effective.

In Subpart B we turn to the harms women experience when denied access to reproductive health services based on providers or employers claiming religious exemption or grounding their refusals in the free exercise of religion. We highlight several cases among the growing number that exemplify the concerns addressed in this Article.

\footnotetext{
74. Id.

75. Id.

76. $I d$.

77. Stein, supra note 31 .
} 


\section{Lori Boyer's Denial of Emergency Contraception After Rape}

"I was so vulnerable ... I felt victimized all over again. First the rape, and then the doctor making me feel powerless." 78

Some doctors and pharmacists refuse to issue emergency contraception even after a woman is raped. In such traumatic instances, being denied care can be devastating and incomprehensible. Understandably, rape victims can be confounded by medical providers' refusal to provide emergency contraception-leading them to incur undue burdens when seeking care elsewhere-if it is available at all.

Lori Boyer's horrific rape occurred at the hands of someone she knew. ${ }^{79}$ As she fled from her rapist, devastated and trembling, she drove to the nearest emergency room, located at Good Samaritan Hospital in Lebanon, Pennsylvania. ${ }^{80}$ Boyer arrived bruised and in terrible pain from the sexual assault. ${ }^{81}$ She tried to remember what women are counseled to do when raped: ask for a rape kit and to talk to a sexual assault counselor. Boyer met with the rape counselor at the hospital who informed her about the "morning-after-pill," which could help to prevent pregnancy. Boyer in turn asked Dr. Martin Gish, who performed the pelvic exam for emergency contraceptives. Gish's response would be burned into her memory. He told her "[n]o," looking back at her chart while saying "I can't do that." $\$ 2$

Boyer recounted that she was in disbelief, trying to "hold back tears." ${ }^{83}$ She explained that if she didn't get the pills, she might become pregnant because she was "midcycle." ${ }^{4}$ According to Boyer, she asked for another doctor and "Dr. Gish simply shook his head." ${ }^{85}$ Gish replied, "It's against my religion." ${ }^{6}$ Through the assistance of the sexual assault counselor, Boyer was able to track down a doctor who would issue the prescription. Yet, the injury of her encounter remained years later. As one reporter noted, "Boyer remained haunted by the ER doctor's refusal." ${ }^{87}$ Her experience with Dr. Gish chilled Boyer's ability to seek gynecological medical care-even routine preventative screenings; she hasn't seen an obstetrician in years. She explained, "I haven't gotten the nerve up to go [to a gynecologist], for fear of being judged again .... The

78. Sabrina Rubin Erdely, Doctors' Beliefs Can Hinder Patient Care: New Laws Shore Up Providers' Right to Refuse Treatment Based on Values, NBC NEWs (June 22, 2007, 2:26 PM), http:// www.nbcnews.com/id/19190916/ns/health-womens_health/t/doctors-beliefs-can-hinder-patient-care/ \#.Ve4fgflVhBd (quoting Lori Boyer).

79. Id.

80. Id.

81. $I d$.

82. Id.

83. $I d$.

84. Id.

85. Id.

86. $I d$.

87. Id. 
whole situation was traumatizing and embarrassing, and I just wanted to put it behind me." ${ }^{\prime 8}$

\section{Tara Harnish: Refused Emergency Contraception After Rape}

"He turned me away when I needed medical help. That's not what a doctor is supposed to do." 89

Tara Harnish suffered a similar experience to that of Lori Boyer: she was raped, sought medical attention, and was refused emergency contraceptives. ${ }^{90}$ Also like Boyer, she sought care at Good Samaritan Hospital in Lebanon, Pennsylvania-in the same emergency room unit. She also was assigned Dr. Martin Gish-the same doctor who refused to provide Lori Boyer emergency contraceptives after she suffered a brutal sexual assault. ${ }^{91}$ For Harnish, the decision to obtain emergency contraception was unequivocal, as she told $\mathrm{ABC}$ News, "[w]ho wants to carry their rapist's baby? Who wants to do that?"92

Harnish's account of Dr. Gish's treatment echoed Boyer's shocking treatment. When Harnish's mother contacted Dr. Gish's office to obtain emergency contraception for her daughter, he refused. According to Harnish, "[h]e seemed more concerned with saving the (potential) pregnancy than he was with my health," she told a reporter. ${ }^{93}$ Harnish was so devastated by her experience that she felt too traumatized to pursue the course of action that rape counselors recommend. ${ }^{94}$ Not only was the hospital aware that Dr. Gish refused to provide standard, recommended care to rape victims, the hospital continued to assign him to rape victims. ${ }^{95}$

Dr. Gish is among a set of doctors who also refuse to refer patients to others who will provide the care their patients' seek. Moreover, some doctors refuse to inform women patients about their medical options, including emergency contraceptives, leaving women with the choice of aborting or carrying an unintended pregnancy to term.

\section{Amanda Renz: Spurned at K-Mart}

Unlike the tragic cases described above, sometimes women simply need their standard birth control pill prescriptions to be filled and yet encounter similar hostility, shaming, embarrassment, and refusal of medical services as those who seek emergency contraceptives. On July 6, 2002,

88. Boyer came forward with her experience after reading about another woman encountering a similar experience. $I d$.

89. Id.

90. Dan Harris, Prescriptions Denied, ABC News.com (Nov. 17, 2006), http://abcnews.go.com/ WNT/story?id=2662616.

91. In July 2006, Harnish sought care at the same emergency ward where Ms. Boyer had previously sought care. Erdely, supra note 78.

92. Harris, supra note 90 (quoting Harnish).

93. Erdely, supra note 78 (quoting Harnish).

94. Id.

95. Id. 
Amanda Renz went to the Menomonie, Wisconsin, K-Mart to refill her birth control prescription. ${ }^{96}$ Pharmacist Neil Noesen was on duty that evening. Ms. Renz, a student at the University of Wisconsin-Stout, did not know that her encounter with Mr. Noesen at K-Mart would lead to future litigation and that she would be in a legal fight regarding birth control. ${ }^{97}$ Renz's prescription was on file at this particular pharmacy.

After presenting her prescription to Mr. Noesen, he asked Amanda whether she intended to use the prescription for contraceptive purposes, to which she answered yes. ${ }^{98}$ Thereafter, Noesen denied Ms. Renz the medication she sought. The State of Wisconsin Pharmacy Examining Board, found that, "[a]fter inquiring whether AR was using the medication for contraception, Respondent did not ask her any further questions and stopped providing any professional services to her." ${ }^{99}$ The disciplinary body also found that "[w]hen AR asked Respondent where she could go to have her prescription refilled, Respondent stated that he would not tell her because he did not want to be a part in her receiving the contraceptives." 100

Noesen broadly defined his religious refusals to include participating in, performing, assisting, recommending, counseling in favor, making referrals for, dispensing, administering, promoting, encouraging, or aiding in the delivery of prescriptions to which he religiously objected. ${ }^{101}$ More specifically, he objected to any "procedure involving a drug or device that may prevent the implantation of a fertilized human ovum." 102 For him, this included "drugs which are prescribed as contraceptives." 103

According to court documents, Noesen informed Amanda of his religious objection and refused to refill the prescription or tell her where and how she could get it refilled. ${ }^{104}$ Timing mattered to Amanda because she needed to begin the first dose of the refill on July 7 th (the next day). ${ }^{105}$ Missing that dose of the medication she sought would then re-

96. Noesen v. State Dep't of Regulation \& Licensing, Pharmacy Examining Bd., 751 N.W.2d 385, 389 (Wis. Ct. App. 2008); see also Amy Bergquist, Pharmacist Refusals: Dispensing (With) Religious Accommodation Under Title VII, 90 MINN. L. REV. 1073, 1073 (2006); Martha S. Swartz, "Conscience Clauses” or "Unconscionable Clauses": Personal Beliefs Versus Professional Responsibilities, 6 YALE J. HeAlth PoL'y L. \& ETHICS 269, 269 (2013) (discussing the Renz case).

97. See In re Disciplinary Proceedings Against Noesen, No. 01 PHM 080, (Wis. Pharmacy Examining Bd. Apr. 13, 2005), available at http://online.drl.wi.gov/decisions/2008/ls0310091phm-0007 7792.pdf (noting that “On Saturday, July 6, 2002, the patient, referred to hereinafter as 'AR', went to the K-Mart Pharmacy and requested a refill of her Loestrin FE $1 / 20$ prescription. AR's prescription had been previously filled at the pharmacy and was on file there.").

98. Id. III $25-26$

99. Id. II 27.

100. Id. II 28.

101. Noesen v. State Dep't of Regulation \& Licensing, Pharmacy Examining Bd., 751 N.W.2d 385, 388 n.1 (Wis. Ct. App. 2008).

102. Id. at 388 n.2.

103. Id.

104. Id. at 389

105. See In re Disciplinary Proceedings Against Noesen, No. 01 PHM 080 (Wis. Pharmacy Examining Bd. Apr. 13, 2005), supra note 97, at III 21-25. 
quire her to obtain a secondary prescription for birth control and to take that alternative contraception for an entire month. ${ }^{106}$

Unfortunately for Amanda, there were no other pharmacists on duty at the time and the managing pharmacist was unable to come to the store. ${ }^{107}$ The Wisconsin Court of Appeals stated, "Noesen did not know, nor did he attempt to ascertain, when Renz needed to start the new pack of pills or how many doses she would miss if the prescription was not filled that day." ${ }^{108}$ Renz then went to a Wal-Mart pharmacy to have the prescription filled. ${ }^{109}$ However, the Wal-Mart pharmacist called K-Mart to transfer the prescription. Noesen again refused to cooperate or provide the necessary information, stating that he believed it would "constitute participating in contraception." 110

Renz did not receive her prescription until two days later, after missing the first dose. ${ }^{111}$ Not only did Noesen refuse to fill the prescription, he also refused to transfer it to a pharmacist who would be willing to provide Ms. Renz birth control. ${ }^{112}$ In rural areas such as Menomonie, Wisconsin, being refused prescription medications based on religious objections can pose extreme burdens on patients. For women, it further exposes them to stigmatization, shaming, emotional distress, and the possibility of litigation to receive basic medical accommodations.

\section{Married and Refused Emergency Contraception, and Other Chilling Narratives}

"I couldn't believe it ... how can they make that decision for us? I was outraged." 113

In Subpart 4, we document cases of doctors and pharmacists refusing to prescribe or dispense contraceptive medications to women who request these services. These cases range, including a college student and even rape victims. Their cases represent a thin slice of those involving women denied reproductive healthcare by medical providers who claim a right to discriminate based on religion and supported by the free exercise clause, state laws, and their religious teachings. There is no way to measure the exact number of women who encounter medical refusals-some women have no idea they were denied an option of care. However, cases abound, and are briefly touched upon here to further illustrate how religious beliefs can dictate and influence a medical provider's willingness to provide certain services.

106. Id. II 42.

107. Noesen v. State Dep't of Regulation \& Licensing, Pharmacy Examining Bd., 751 N.W.2d 385, 389 (Wis. Ct. App. 2008).

108. Id.

109. Id.

110. Id.

111. Id. III 24, 43.

112. A prescription transfer must be completed by communication between two pharmacists. See WIS. ADMIN. CODE § Phar 7.055(1)(a) (2006).

113. Stein, supra note 31 (quoting Pulz). 
For example, when Kathleen Pulz and her husband thought their regular method of birth control (a prophylactic condom that broke) made them susceptible to an unintended pregnancy, she sought emergency contraception at the local Walgreens in Milwaukee, Wisconsin. ${ }^{114}$ The pharmacy, however, refused to fill the emergency prescription. Pulz and her husband worried that they could not afford a fifth child. Pulz was outraged after being denied the medication she sought. She did not know that Walgreens and several other pharmacies allow their pharmacists to refuse to dispense medications based on religious objections. Pulz considered herself lucky because she ultimately obtained the medication directly from her doctor. Often patients are able to obtain their medications elsewhere, but the toll on them may be traumatizing and extreme. ${ }^{115}$

In Cheryl Bray's case, after undergoing the extensive and sometimes arduous process to adopt, one last hurdle involved a routine medical examination to confirm her physical fitness to parent. ${ }^{116}$ She did not anticipate a problem with this routine physical exam, because she was healthy and 41 years of age. However, Dr. Fred Salley, who was recommended by a friend, asked, "[s]o, your husband is in agreement with your decision to adopt?" 117 When Bray explained that she was not married, Dr. Salley told her "[ $t]$ hen I'm not comfortable continuing this exam." ${ }^{118}$ Salley later told a reporter that Bray's recalling of their interaction was not accurate. According to Salley, his decision not to examine Bray and complete the necessary paperwork "was not because she was unmarried; rather, it was based on my moral belief that a child should have two parental units," and "such religious beliefs are a fundamental right guaranteed by the Constitution of the United States." 119

Sometimes, religious refusals are life and death matters. In December 2010, when Tenesha Means was eighteen weeks pregnant, her water broke and she went to Mercy Health Partners ("MHP"), a Catholic hospital and the only hospital within thirty minutes of her home. ${ }^{120}$ Despite the urgency of her health condition, Means was sent home and told to consult with her doctor at an appointment she had scheduled for more than a week later. ${ }^{121}$ The next day, Means returned to MHP bleeding and experiencing painful contractions but was again sent home. That night, Means again returned to MHP "in pain, in distress, and with signs of an infection." "122 MHP was preparing to send her home again when the fetus's feet breached her cervix and she began to deliver. ${ }^{123}$ The baby died

114. Id.

115. See, e.g., id.

116. Erdely, supra note 78.

117. Id.

118. Id.

119. Id.

120. Complaint at 2, Means v. U.S. Conference of Catholic Bishops, No. 2:13CV14916, 2013 (E.D. Mich. Nov. 28, 2013).

121. Id.

122. Id. at $2-3$.

123. Id. at 3 . 
shortly after birth. ${ }^{124}$ At no time was Means informed that her fetus had no chance of surviving and that continuing her pregnancy would pose a serious risk to her health, including infection and possible death. ${ }^{125}$ Nor was Ms. Means informed that the safest treatment option was to induce labor and terminate the pregnancy. Doctors refused to provide this information based on religious grounds, although it caused direct pain and injury to Means. ${ }^{126}$

In Brittany Cartrett's case, at Walmart in Milledgeville, Georgia,where she previously worked-the pharmacist refused to fill a prescription for Misoprostol. Brittany's doctor prescribed the drug because she miscarried during the first trimester of her pregnancy. ${ }^{127}$ She decided not to have a surgical procedure to remove the fetus, but instead to "pass [the fetus] naturally" to avoid "the more invasive route." ${ }^{128}$ Her doctor prescribed Misoprostol, which can induce an abortion, for that reason. However, Cartrett said the pharmacist told her, "I couldn't think of a reason why you would need that prescription." 129

So the drug was not filled at Walmart. Brittany had to find another pharmacist to procure the drug. When one reporter contacted Walmart, she was told, "the pharmacist had a professional judgment call against filling the prescription, not any other reason. They're well within their rights, the pharmacists, to not agree that a specific prescription should be filled." ${ }^{130}$ However, Brittany feared that if this tragic situation happened to her, there might be other women who experienced similar refusals during miscarriage. In fact, upon hearing her story, other women in Georgia contacted her sharing similar encounters-in one case, the woman opted for the abortion when pharmacists refused to dispense the prescription to help with her miscarriage. ${ }^{131}$

The central justification for denying medical services in each of the cases described in Part II is a religious objection. The central issue then is whether the free exercise clause protects health care providers' decisions to deny medical services to women who need them. We take up that issue and conscience clauses in Part III.

124. Id.

125. Id. at $2-3$.

126. Id. at 3 .

127. Noelle Kachinsky, Milledgeville Pharmacist Refuses to Fill Prescription for Miscarriage Patient, WGXA TV NEws (Apr. 10, 2015), http://wgxa.tv/news/local/milledgeville-pharmacist-refuses-tofill-prescription-for-miscarriage-patient.

128. Id.

129. Amanda Marcotte, A Miscarrying Woman Was Denied Medication Because of "Conscience," SLATE (Apr. 14, 2015, 3:14 PM), http://www.slate.com/blogs/xx_factor/2015/04/14/miscarrying_woman _denied_medication_misoprostol_can_be_used_for_both_abortion.html.

130. Molly Redden, The Scary Law that Allowed Pharmacists to Deny this Woman the Drugs She Needed After Her Miscarriage, MOTHER Jones (Apr. 16, 2015, 10:33 AM), http://www.motherjones. com/politics/2015/04/pharmacists-refused-woman-drugs-miscarriage-walmart.

131. Id. 


\section{THE LEGAL LANDSCAPE}

The question for law is whether the free exercise of religion provides a right to health care providers to inflict injuries on their patients and those who seek their services. We believe that it does not. Our thesis is that the First Amendment's Free Exercise of Religion Clause is not absolute; it does not grant a right to impose harms or inflict injuries on others. We find these actions particularly troubling in the medical context where refusing to provide medical care or fill a prescription could be a matter of life or death. So where does the confusion on this question emerge, leading some to believe that they have a legal right, based on religion, to discriminate?

Some states and the federal government carve out religious exceptions or exemptions for individuals with closely held beliefs. Yet, the question remains, do such laws seek to protect those with closely held religious beliefs from discrimination or grant "believers" the right to discriminate? Our normative argument, taken up in Part IV, is that such laws should not serve as a legal justification inflicting harm on others nor for permitting discrimination whether based on sex, sexual orientation, race, or other factors.

\section{A. Historical Perspective}

According to Sanford H. Cobb in The Rise of Religious Liberty in America: A History, in contrast to the approaches adopted by many European countries that "assumed the necessity of a vital relation between Church and State," the U.S. embraced a dramatically different approach, which guarded state intrusion into religion and the "church's" influence or dictate to the state. ${ }^{132}$ Hence the common adage, "separation of church and state" is embedded within law.

This view suggests broad individual rights to practice one's religion, without intrusion or interference by the state, with the only limitations to prevent endangering society's safety, moral order, or imposing harms on others. For example, Rhode Island's 17th Royal Century Charter, which was the first to involve the terminology "liberty of conscience," guaranteed the protection of its citizens' "conscience." 133 Notably, however, the Royal Charter prohibited those exercising their "religious conscience" from causing civil injury or disturbing others. ${ }^{134}$

Much of the discussion of the Free Exercise Clause (which is limited in comparison to scholarly discussion of the Establishment Clause) ${ }^{135}$

132. SANFORD H. COBB, THE Rise OF REligious LibERTy IN AMERICA: A History 1-2 (1902), available at https://archive.org/stream/riseofreligiou00cobb\#page/n6/mode/1up.

133. See Rhode Island Royal Charter of 1663, available at http://sos.ri.gov/divisions/Civics-AndEducation/charter-1663.

134. See id.

135. Michael W. McConnell, The Origins and Historical Understanding of Free Exercise of Religion, 103 HARV. L. REV. 1409, 1414 (1990) (noting that, in comparison to scholarship on the estab- 
looks to the records of the First Congress and the positions held by the drafters regarding whether the clause recognizes religious exemptions to protect free exercise. Nowhere in the records we probed or the lawjournal articles we reviewed was there ever an articulated right permitting discrimination against citizens based on religion. Rather, early records point to law, protecting religious minorities from the tyranny of others. ${ }^{136}$

We turned to a detailed analysis of whether the Free Exercise Clause requires granting religious exemptions from generally applicable laws with secular purposes, written by Professor Michael McConnell. ${ }^{137}$ Professor McConnell meticulously describes combing through preConstitution American history to further illume both the historical roots and intent behind the Free Exercise Clause. ${ }^{138}$ His approach stemmed from the premise that "[t]he free exercise clause cannot be understood or appreciated without knowing what happened before." 139

According to McConnell, the term "free exercise" first appeared in a 1648 document, in which Lord Baltimore required the new Protestant governor and councilors in Maryland to "promise not to disturb Christians . . . in the 'free exercise' of their religion." ${ }^{40}$ And in 1649, the Maryland Assembly enacted the first "free exercise" clause on the continent, which stated that

[N]oe person ... professing to beleive in Jesus Christ, shall from henceforth bee any waies troubled ... for ... his or her religion nor in the free exercise thereof . . nor any way [be] compelled to the beliefe or exercise of any other Religion against his or her own consent [sic]..$^{141}$

Rhode Island's Royal Charter of 1663 provided that no resident could be in "any wise molested, punished, disquieted, or called into question, for any difference in opinione in matters of religion, [that] doe not actually disturb the civill peace of our sayd colony," as long as they were not using this liberty "to lycentiousnesse and profanenesse, nor to the civill injurye or outward disturbeance of others [sic]." ${ }^{142}$

This broad approach adopted by Rhode Island corresponds with the ideals established and embedded into law over a century later in the U.S. Constitution. According to McConnell, the substance of Rhode Island's provision "re-emerged as the most common pattern in the constitutions

\footnotetext{
lishment clause, "little or no scholarly work has been devoted primarily to the history of the concept of "free exercise of religion.").

136. See generally Vincent Phillip Muñoz, The Original Meaning of the Free Exercise Clause: The Evidence from the First Congress, 31 HARV. J.L \& PUB. POL'Y 1083 (2008).

137. McConnell, supra note 135 , at 1421.

138. Id.

139. Id.

140. Id. at 1425 (citing William T. Russell, MARYland: The LAND OF THE SANCTUARY 130 (1908)).

141. Id. (citing Act Concerning Religion of 1649).

142. See Rhode Island Royal Charter of 1663, supra note 133; McConnell, supra note 135, at $1425-26$.
} 
adopted by the states after the [American] Revolution" and, arguably, by the Federal Constitution as well. ${ }^{143}$ Early freedom of exercise clauses were quite broad, which McConnell regards as supporting a broader interpretation of religious rights and exemptions based on free exercise. ${ }^{144}$ Under the second Charter of Carolina in 1665, for example, explicit free exercise exemptions were provided. ${ }^{145}$ The Charter recognized that "it may happen that some of the people and inhabitants of the said province cannot, in their private opinions, conform" 146 to the Church of England. The Charter, therefore, allowed proprietors "to give and grant unto such person and persons... such indulgences and dispensations, in that behalf ... [as they] think fit and reasonable . . ." ${ }^{147}$ It sought to protect individuals from being "molested, punished, disquieted, or called in question, for any differences in opinion ...."148

Relevantly, the Charter did not grant an absolute religious liberty. Limitations were embedded within the law just as with the Rhode Island Charter. For example, religious liberty or free exercise did not permit those exercising religious freedom to cause "disturbance" to others. ${ }^{149}$ Nor did free religious exercise permit, justify, or excuse inflicting harms on others. The Charter specified, "in matters of religion" the liberty could not be used for "civil injury, or outward disturbance of others ...." 150

In addition to the colonies' various approaches to church-state relations, the drafters of the U.S. Constitution were also influenced by a variety of political thinkers. John Locke's work is particularly relevant because of his extensive discussion of religion's role in matters of the state and his deep influence on many of the drafters, including Thomas Jefferson. ${ }^{151}$ "Major portions of Jefferson's Bill for Establishing Religious Freedom," which was a major precursor of the free exercise clause, were derived from passages in Locke's work. ${ }^{152}$

Importantly, Locke was a strong and influential proponent for religious freedom on theoretical grounds. He believed "[r]eligious intolerance was inconsistent both with public peace and good government." ${ }^{153}$ To resolve these issues, Locke argued for a "modification of the nature and claims of religion and an abandonment of the government's role in

\footnotetext{
143. McConnell, supra note 135, at 1425-27.

144. Id. at $1427-28$

145. See Charter of Caroline: June 30, 1665, available at http://avalon.law.yale.edu/17th_century /nc04.asp.

146. Id.

147. Id.; see also McConnell, supra note 135, at 1428 (“'Indulgences' and 'dispensations' are technical legal terms ... referring to the King's asserted power to exempt citizens from enforcement of [laws] enacted by Parliament.").

148. See Charter of Caroline, supra note 145.

149. Id.

150. Id.

151. McConnell, supra note 135 , at 1430 .

152. Id. at $1430-31$

153. Id. at 1431 .
} 
upholding religious truth." ${ }^{154} \mathrm{He}$ believed enforcing religious unity exacerbated rather than ameliorated the problem. Because diversity of opinions "cannot be avoided," the better approach was tolerance of different opinions. ${ }^{155}$

Notably, however, Locke viewed religious strife as stemming from "the tendency of both religious and governmental leaders to overstep their bounds and intermeddle in the others' province." 156 Thus, although much of the discussion about freedom of religion centers around how much the government can interfere in religious practices, Locke recognized that the opposite can also occur when religious leaders and institutions try to inappropriately insert themselves into matters better left to the government or other entities. Locke acknowledged that religion must be protected, but also limited, so as to avoid meddling with others. ${ }^{157}$

The important lessons from this historical view are at least twofold. First, early thinkers about religious liberty strove to enact laws that protected the quiet enjoyment of religion. They sought to protect religious minorities and others from persecution and punishment based on their difference of opinion. That is, the horrors to which religious minorities were subjected in England would not be carried out nor condoned in the newly established colonies. Second, framers of these early charters consistently imposed specific limitations on religious freedom. Religious liberty did not grant a right to harm others. Religious freedom could not be used to cause the disturbance or injury to others.

\section{B. State Laws}

As described above, early charters establishing laws in colonies protected religious conscience. The protections could be viewed as negative protections - that is, they protected individuals from harm for expressing or holding religious opinions. They did not provide exemptions, per se. The modern view is more complicated. A mishmash of state laws intervene on the question of how far one's religious liberty extends. For example, some states have enacted conscience clauses that allow individuals to legally claim an exception or exemption from performing certain duties or tasks. State Religious Freedom Restoration Acts ("RFRAs") also provide protections to those who claim religious entitlements. Finally, child abuse statutes throughout the U.S. carve out protections or exceptions for parents who claim a religious objective to justify negligent or abusive conduct toward their children.

154. Id.

155. John Locke, A LeTter CONCERning TOLERATION AND OTHER Writings 60 (Mark Goldie \& David Womersley eds., 2010).

156. McConnell, supra note 135, at 1432 (emphasis added).

157. LOCKE, supra note 155, at 152-54 (outlining "ecclesiastical power"). 


\section{Conscience Clauses}

Conscience clauses serve as powerful, political counter-responses to the U.S. Supreme Court's decision in Roe v. Wade. ${ }^{158}$ In response to that landmark case, states sought to protect the interests of those religiously opposed to abortion by enacting or expanding conscience clauses or laws. ${ }^{159}$ Thus, conscience clauses provided the means and legal protection to individuals and institutions (professing sincerely held religious beliefs) to refuse to provide, assist, or otherwise facilitate abortions or sterilization. ${ }^{160}$ Nearly all of those affected by such clauses are women, and among them the poor experience reproductive disenfranchisement most severely.

In fact, the majority of states enacted "Conscience Laws" that essentially codify religious exemptions and exceptions. ${ }^{161}$ In broad terms, forty-five states permit a healthcare provider the right to refuse to provide abortion services. ${ }^{162}$ Eighteen states allow the refusal to provide sterilization services. ${ }^{163}$ And twelve states have legalized healthcare providers' right to deny dispensing contraceptives to women seeking such services. ${ }^{164}$

Many conscience laws permit and protect a health care provider's or institution's refusal to provide or participate in reproductive health care services such as abortion and sterilization. ${ }^{165}$ Montana's law, for example, permits all persons to refuse to participate in a sterilization based on moral convictions. ${ }^{166}$ Separate federal laws and regulations, such as Title VII of the Civil Rights Act of 1964, prohibit employers from discriminating against current or potential employees "based on religion, including religiously based objections to performing specific job functions . . .."167 Most recently, RFRA was invoked to exempt "closely held" for-profit

158. See Roe v. Wade, 410 U.S. 113 (1973); see also infra note 160 and accompanying text

159. Guttmacher Inst., State Policies in BRIEF: Refusing to Provide HeAlth SeRVICES 1 (Feb. 1, 2015), available at http://www.guttmacher.org/statecenter/spibs/spib_RPHS.pdf.

160. See, e.g., Claire Marshall, The Spread of Conscience Clause Legislation, 39 A.B.A. HUM. RTS. 2 (2013), available at http://www.americanbar.org/publications/human_rights_magazine_home/2013_ vol_39/january_2013_no_2_religious_freedom/the_spread_of_conscience_clause_legislation.html;

Pharmacist Conscience Clauses: Laws and Information, NCSL, http://www.ncsl.org/research/health/ pharmacist-conscience-clauses-laws-and-information.aspx (last updated May 2012).

161. GUTTMACHER INST., supra note 159 , at 1.

162. Id. at 2 .

163. Id.

164. Id.

165. See, e.g., MONT. CODE ANN. § 50-5-503 (2014) ("All persons shall have the right to refuse to advise concerning, perform, assist, or participate in sterilization because of religious beliefs or moral convictions."); 43 PA. STAT. ANN. § 955.2(a) (2014) ("No hospital or other health care facility shall be required to, or held liable for refusal to, perform or permit the performance of abortion or sterilization contrary to its stated ethical policy. No physician, nurse, staff member or employe[e] of a hospital or other health care facility, who shall state in writing to such hospital or health care facility an objection to performing, participating in, or cooperating in, abortion or sterilization on moral, religious or professional grounds, shall be required to, or held liable for refusal to, perform, participate in, or cooperate in such abortion or sterilization."); see also GUTTMACHER INST., supra note 159, at 1.

166. See, e.g., MONT. CODE ANN. § 50-5-503 (2014)

167. GUTTMACHER INST., supra note 159 , at 1. 
corporations from the ACA requirement to cover contraception for their employees. ${ }^{168}$

Originally, the term "conscientious objection" referred to the refusal to perform mandatory military service based on religious or moral objections to killing: ${ }^{169}$ today, the term is repeatedly invoked in health care. ${ }^{170}$ Because some health-care providers believe they have a right to deny providing medical services that conflict with their religious beliefs, we turn to the law on this matter. In the wake of Roe v. Wade and Doe v. Bolton, decisions that "legalized abortion nationwide, federal and state governments ... enacted laws that allow health care professionals and institutions to refuse to provide services related to reproductive health without facing legal, financial or professional consequences.” ${ }^{171}$ These laws, however, are distinct from another set of laws: RFRAs.

\section{Religious Freedom Restoration Acts}

More than a third of U.S. states have enacted RFRAs-eighteen to be exact. These laws impose a significant obstacles on government entities seeking to burden religious freedom, because states may not substantially burden religious freedom. State RFRAs require that the government be held to a strict scrutiny standard when they burden religion. Yet, despite RFRAs protections, one professor notes, "[i]n most places, state RFRAs simply have not translated into a dependable source of protection for religious liberty at the state level." 172 This may have much to do with the types of cases brought and the perceived rights at stake. In other words, was the party seeking religious protection discriminated against by the state or seeking to discriminate against others? As to the former, courts are far more sympathetic. As to the latter, despite a spate of litigation, courts are rightfully far more cautious and reluctant to extend religious protection to harmful conduct against others.

That state courts are disinclined to expand religious freedom to include granting a right to harm others may be the reason that so few state RFRA cases have been adjudicated. For the most part, states do a pretty good job of protecting individuals from harm based on their religion. That said, the upswing in religious exception cases is a modern trend, which may have a significant impact at the state court level.

168. See Burwell v. Hobby Lobby Stores, Inc., 134 S. Ct. 2751, 2759 (2014).

169. Joyce Arthur \& Christian Fiala, Why We Need to Ban 'Conscientious Objection' in Reproductive Health Care, RH REALITY CHECK (May 14, 2014, 1:56 PM), http://rhrealitycheck.org/ article/2014/05/14/why-we-need-to-ban-conscientious-objection-in-reproductive-health-care.

170. Id.

171. GUTTMACHER InST., supra note 159, at 1; see also Roe v. Wade, 410 U.S. 113 (1973); Doe v. Bolton, 410 U.S. 79 (1973).

172. Christopher C. Lund, Religious Liberty After Gonzales: A Look at State RFRAS, 55 S.D. L. REV. 466, 468 (2010). 


\section{Child-Abuse Statutes}

Nearly all states enacted laws that carve out religiously based protections for those who harm their children. These laws were ubiquitously ushered through legislatures in the wake of congressional passage of the Child Abuse Prevention and Treatment Act ("CAPTA"), which was originally enacted on January $31,1974 .{ }^{173}$ CAPTA "provides Federal funding to States in support of prevention, assessment, investigation, prosecution, and treatment activities and also provides grants to public agencies and nonprofit organizations . ..."174 Ironically, that law, as discussed infra, and state laws actually carved out exceptions based on religion.

For example, Florida's law relating to children and child abuse carves out the following exception: "a parent or legal custodian who, by reason of the legitimate practice of religious beliefs, does not provide specified medical treatment for a child may not be considered abusive or neglectful ...." 175 The law further allows a court to order "treatment by a duly accredited practitioner who relies solely on spiritual means for healing in accordance with the tenets and practices of a well-recognized church or religious organization." 176

Kentucky's child abuse statute substantively mirrors that of Florida. It provides that "a parent or other person exercising custodial control or supervision of the child legitimately practicing the person's religious beliefs shall not be considered a negligent parent solely because of failure to provide specified medical treatment for a child for that reason alone." 177 Arizona laws specifically protect parents who practice Christian Science from presumptions of neglect and child abuse. Their laws in separate statutes provide, "[no] child who in good faith is being furnished Christian Science treatment by a duly accredited practitioner shall, for that reason alone, be considered to be an abused, neglected or dependent child." ${ }^{178}$ Similarly, laws from Alabama, ${ }^{179}$ Alaska, ${ }^{180}$ Arkansas, ${ }^{181}$ Del-

173. 42 U.S.C. ch. 67 § 5101-5119c (1974); see also, CHILD WELFARE INFORMATION GATEWAY, U.S. DeP'T OF HeAlth \& Human Serv., AbOUt CAPTA: A Legislative History 1 (2011), available at https://www.childwelfare.gov/pubPDFs/about.pdf.

174. CHILD WELFARE INFORMATION GATEWAY, supra note 173, at 1.

175. FLA. STAT. §39.01(30)(f) (2015).

176. Id.

177. KY. REV. STAT. ch. 600.020 § 1(a)(8) (2015), available at http://www.lrc.ky.gov/Statutes/ statute. $\operatorname{aspx}$ ?id $=40868$.

178. ARIZ. REV. STAT. ANN. § 8-201.01 (2014); §8-531.01 (dealing with termination of parental rights).

179. ALA. CODE $§ 26-14-7.2$ (a) (2013).

180. ALASKA STAT. \$ 47.17.020(d) (2015) ("This section does not require a religious healing practitioner to report as neglect of a child the failure to provide medical attention to the child if the child is provided treatment solely by spiritual means through prayer in accordance with the tenets and practices of a recognized church or religious denomination by an accredited practitioner of the church or denomination.").

181. In Arkansas, when a child has been found to be abused, state officials may not officially enter such a judgment "when a parent practicing his religious beliefs does not, for that reason alone, provide medical treatment for a child, but in lieu of such treatment the child is being furnished with treatment by spiritual means alone, through prayer, in accordance with a recognized religious method 
aware, ${ }^{182}$ Iowa, ${ }^{183}$ Kansas, ${ }^{184}$ Louisiana, ${ }^{185}$ Minnesota, ${ }^{186}$ New Hampshire, ${ }^{187}$ and Vermont, ${ }^{188}$ among others, protect those claiming religious exemptions from even providing physical therapy for their sick children. According to Children's Healthcare Is a Legal Duty, more than a handful of states permit religious exemptions for negligent homicide, manslaughter, or capital murder, including West Virginia and Arkansas. ${ }^{189}$

\section{Federal Laws and the Religious Freedom Restoration Act of 1993}

A broad jumble of federal laws unambiguously and unequivocally permit many health service providers, and the institutions in which they work, the right to refuse to provide medical accommodations related to sterilization services and abortion. ${ }^{190}$ For example, shortly after the Supreme Court's Roe v. Wade ruling Congress enacted the Church Amendment, ${ }^{191}$ which provides that health care entities receiving certain federal funds may not lose funding because a doctor "refuse[d] to perform or assist in the performance of such a procedure or abortion on the grounds that his performance or assistance ... would be contrary to his religious beliefs or moral convictions, or because of his religious beliefs or moral convictions respecting sterilization procedures or abortions." 192 According to the Guttmacher Institute, "[c]ollectively, these laws prevent government agencies from forcing the provision of services or 'discriminating' against individuals and institutions that refuse to provide them ...." ${ }^{193}$ As previously referenced, federal laws also carve out exceptions for parents who refuse to provide medical care for their children based on religion —or who choose prayer over medicine.

\footnotetext{
of healing by an accredited practitioner." ARK. CODE ANN. § 12-12-512(a)(2)(C) (repealed 2009), available at $\mathrm{http}: / /$ childrenshealthcare.org/?page_id=3119.

182. Del. CODE ANN. tit. 13, § 1103(c) (West 2013).

183. IOWA CODE $\$ 232.68(4)$ (c) (2014).

184. KAN. STAT. ANN. § 38-1502(b) (repealed 2006), available at http://childrenshealthcare.org/? page_id=3119.

185. LA. CHILD. CODE ANN. art. 603(18) (2015). Louisiana law also exempts religious practitioners from mandated reporting of child abuse. Id. art. 603(17)(c). And protects custodial rights of parents who deny their children medical attention based on religious beliefs. Id. art. 1003(10) (2014).

186. MinN. STAT. $\$ 626.556(2)(\mathrm{g})(5)(2015)$.

187. N.H. REV. STAT. ANN. § 169-C:3(XIX)(c) (2014).

188. VT. STAT. ANN. tit. 33, § 4912(6)(B) (2015).

189. Religious Exemptions to Medical Treatment of Children in State Civil \& Criminal Codes,

CHILD, INC. (Apr. 29, 2015), http://childrenshealthcare.org/?page_id=3119.

190. GUTTMACHER INST., supra note 159 , at 1.

191. 42 U.S.C. $\$ 300 a-7(2000)$.

192. Id. $\S 300 \mathrm{a}-7(\mathrm{c})(1)(\mathrm{B})$

193. GUTTMACHER INST., supra note 159 , at 1.
} 


\section{CAPTA}

As described above, in 1974, Congress enacted CAPTA with the purpose to reduce child abuse and neglect. ${ }^{194}$ As detailed in Subpart B, the law embedded an exception to civil punishment for the neglect or abuse of children based on religion. The law reads in pertinent part:

A parent or guardian legitimately practicing his religious beliefs who thereby does not provide specific medical treatment for a child, for that reason alone shall not be considered a negligent parent or guardian. Such exception, however, shall not preclude a state from ordering medical services be provided to the child, where his health requires it. ${ }^{195}$

Critics argue that, although CAPTA is "the first major child welfare statute, there are no specific enforcement mechanisms" 196 and its religious exemptions may have been influenced by aides to President Richard Nixon-H.R. Haldeman, the former president's Chief of Staff and John Ehrlichman, Nixon's chief advisor for domestic affairs, who were both Christian Scientist. ${ }^{197}$ In his book, Bad Faith, Dr. Paul Offit argues that Ehrlichman and Haldeman inserted the religious exemption into CAPTA. ${ }^{198}$

More importantly, the law's religious exemptions influenced the development of such exemptions at the state level and profoundly impacted children's health in some communities where parents traditionally pray rather than provide medical care for their children. If states refused to abide by CAPTA, they risked losing federal funds. ${ }^{199}$ Soon thereafter forty-nine states adopted laws with similar language. ${ }^{200}$ As of 2013, "thirtyeight states and the District of Columbia still had religious exemptions for child abuse in their civil codes, and seventeen had religious exemptions for felony crimes." ${ }^{201}$ According to the children's advocacy group, CHILD, in Idaho, where robust exemptions were enacted in the wake of CAPTA, " 200 of the 600 graves in one cemetery used by an Idaho faithhealing sect are of minor children." ${ }^{202}$ In 1984, HHS eliminated the mandate. Dozens of states, however, maintain their religious exemption clauses.

194. Walter Wadlington, Medical Decision Making for and by Children: Tensions Between Parent, State, and Child, 1994 U. ILL. L. ReV. 311, 324 (1994).

195. Religious Exemptions, supra note 189.

196. Gerard F. Glynn, The Child's Representation Under CAPTA: It Is Time For Enforcement, 6 NEV. L. J. 1250, 1257 (2006).

197. See Paul Offit, Bad Faith: When Religious Belief Undermines Modern Medicine 170-71 (2015); Abraham Verghese, 'Bad Faith,' by Paul A. Offit, N.Y. Times (April 10, 2015), http://www.nytimes.com/2015/04/12/books/review/bad-faith-by-paul-a-offit.html?_r=0.

198. OFFIT, supra note 197, at 171 (arguing that Haldeman and Ehrlichman "tipped their hand; only Christian Scientists would refer to their prayers as treatments and to their faith healers as practitioners; and only the Christian Science Church accredits its healers.").

199. See id.

200. See id.

201. Id. at 172

202. See Religious Exemptions, supra note 189. 


\section{RFRA}

The First Amendment establishes that "Congress shall make no law respecting an establishment of religion, or prohibiting the free exercise thereof . ..." ${ }^{203}$ These two historic clauses, respectively referred to as the "Establishment Clause" and the "Free Exercise Clause," frame the broader boundaries of religiously based legal rights in the U.S. ${ }^{204}$ Neither clause, on its face, comports with an understanding that religion trumps other important legal and social values.

However, religious-based rights or exemptions from obligated actions are not exclusively governed by the U.S. Constitution. In recent years, debates about religious freedom often involve RFRA, which constrains government from

[S]ubstantially burden[ing] a person's exercise of religion even if the burden results from a rule of general applicability .... [Unless] it demonstrates that application of the burden to the person-(1) is in furtherance of a compelling governmental interest; and (2) is the least restrictive means of furthering that compelling governmental interest. 205

Congress enacted RFRA in response to growing concern that free religious exercise was at risk after the U.S. Supreme Court's decision in Employment Division v. Smith, which established that laws burdening religious exercise are constitutional so long as the prohibition is not the law's purpose "but merely the incidental effect of a generally applicable and otherwise valid provision." ${ }^{206}$ The Smith decision was attacked by some religious groups, which perceived and declared religious liberty in danger by courts. ${ }^{207}$

The Court's decision in Smith contrasted to the approach taken in Sherbert $v$. Verner. ${ }^{208}$ In the latter case, the Court ruled that Adell Sherbert's employer had placed a substantial infringement on her constitutional right to freely exercise her religion by extending her work hours to include Saturdays, which, as a Seventh-day Adventist, was a day she was religiously obliged not to work. ${ }^{209}$ The case established the so-called "Sherbert Test," which served as the legal standard until Smith. ${ }^{210}$

The Sherbert Test required an individual to first prove a sincere religious belief and a substantial burden on that belief through government

203. U.S. CONST. amend. I.

204. See First Amendment and Religion, U.S. COURTS, http://www.uscourts.gov/educationalresources/educational-activities/first-amendment-and-religion (last visited Mar. 11, 2016).

205. 42 U.S.C. $\S 2000 b b-1(a)-(b)(2012)$.

206. Emp't Div. v. Smith, 494 U.S. 872, 878 (1990).

207. Douglas Laycock, The Remnants of Free Exercise, 1990 SuP. CT. REV. 1, 1-2 (1990) (noting the "substantial scholarly criticism" of Smith); McConnell, supra note 135, at 1414 (noting that, in comparison to scholarship on the establishment clause, "little or no scholarly work has been devoted primarily to the history of the concept of "free exercise of religion."').

208. 374 U.S. 398 (1963).

209. Id. at 403 .

210. See Zak Lutz, Limits of Religious Freedom, HARV. Pol. REV. (May 27, 2013, 11:25 PM), http://harvardpolitics.com/covers/limits-of-religious-freedom/. 
action. ${ }^{211}$ If these two elements were established, the action was unconstitutional unless the government proved a compelling state interest carried out in the least intrusive way possible. The Sherbert Test was rejected in Smith but then codified in RFRA.

Indeed, Congress affirmed that the purpose of RFRA was "to restore the compelling interest test as set forth in Sherbert v. Verner and Wisconsin v. Yoder, to guarantee its application in all cases where free exercise of religion is substantially burdened, and to provide a claim or defense to persons whose religious exercise is substantially burdened by government." 212

However, is the current approach to religious exemptions, as codified in RFRA, supported by historical views on free exercise? Historically, what was the intent of the Free Exercise Clause and how did legal scholars initially interpret the scope of the clause? Two leading interpretations have emerged in recent years: the "exemption" view (as exemplified by RFRA) that the Free Exercise Clause grants religious individuals and institutions exemptions from generally applicable laws that substantially burden religious exercise without a compelling state interest; and the "non-exemption" view (following Smith) which challenges the perspective that the Free Exercise Clause encompasses such exemptions. ${ }^{213}$

RFRA figured significantly in Burwell v. Hobby Lobby Stores, Inc. ${ }^{214}$ At issue in Hobby Lobby was whether the federal RFRA ${ }^{215}$ permitted the HHS to require "closely held corporations" to provide their employees with health insurance coverage for contraceptives that violate the corporation owners' sincerely held religious beliefs. ${ }^{216}$

The ACA requires specific employer group health plans to provide women "preventative care and screenings" without "any cost sharing requirements." ${ }^{17}$ The ACA authorizes the Health Resources and Service Administration ("HRSA") to promulgate "comprehensive guidelines" enumerating the types of preventive care and services that must be covered. ${ }^{218}$ "The guidelines provide that nonexempt employers are generally required to provide coverage, without cost sharing, for all Food and Drug Administration ("FDA") approved contraceptive methods, sterilization procedures, and patient education and counseling." ${ }^{219}$ Despite the fact that most FDA-approved contraceptives work by preventing fertilization of an egg, some argue that four approved methods-those specifically at issue in Hobby Lobby - may "prevent[] an already fertilized egg

211. Id.

212. 42 U.S.C. $\$ 2000 b b(b)$ (2012) (citations omitted).

213. See Muñoz, supra note 136, at 1083-84.

214. 134 S. Ct. 2751 (2014)

215. See 42 U.S.C. $\$ \$ 2000 b b$.

216. Hobby Lobby, 134 S. Ct. at 2759

217. 42 U.S.C. $\$ 300 g g-13(a)(4)$ (2012).

218. Id.

219. Hobby Lobby, 134 S. Ct. at 2762 (internal quotation marks omitted). 
from developing any further by inhibiting its attachment to the uterus." 220 This, as argued by Hobby Lobby, is equivalent to an abortion. ${ }^{221}$

Owners of "closely held" corporations ${ }^{222}$ with sincere religious beliefs against at least four of the contraceptives required to be covered under the ACA sued HHS, arguing that the regulations violated RFRA. ${ }^{223}$ The corporations claimed that it was "immoral and sinful for [them] to intentionally participate in, pay for, facilitate, or otherwise support these drugs." 224

In a 5-4 decision, the Supreme Court held that the regulations violated RFRA. ${ }^{225}$ The Court concluded that the regulations substantially burdened the owners' exercise of religion because they were contrary to the owners' religious objections to abortion and because there was a heavy financial penalty for noncompliance. ${ }^{226}$ Assuming that the regulations served a compelling government interest, ${ }^{227}$ the Court concluded that the regulations were not the "least restrictive means" of serving that interest because there were other methods to ensure women have costfree access to these contraceptives. ${ }^{228}$ For example, the Court argued that the Government can assume the cost of providing the four contraceptives at issue to women unable to obtain them because of their employers' religious objections. ${ }^{229}$

Hobby Lobby introduces new parties to the trend of exceptionalism in health care: insurance companies and closely-held for-profit corporations. Hobby Lobby, however, is viewed and described as only reaching issues of contraception, and that is generally a fair characterization of the case. The Court explicitly stated that its decision:

is concerned solely with the contraceptive mandate .... [And] should not be understood to hold that an insurance-coverage mandate must necessarily fall if it conflicts with an employer's religious beliefs. Other coverage requirements, such as immunizations, may be supported by different interests . . . and may involve different arguments about the least restrictive means of providing them. ${ }^{230}$

In a robust dissent, Justice Ginsburg scrutinized Hobby Lobby's limits, questioning where exactly the contours will fall. She questioned, "where is the stopping point to the "let the government pay' alternative?" ${ }^{311}$ She hypothesized, an example, "an employer's sincerely held religious belief is offended by health coverage of vaccines, or paying the minimum wage

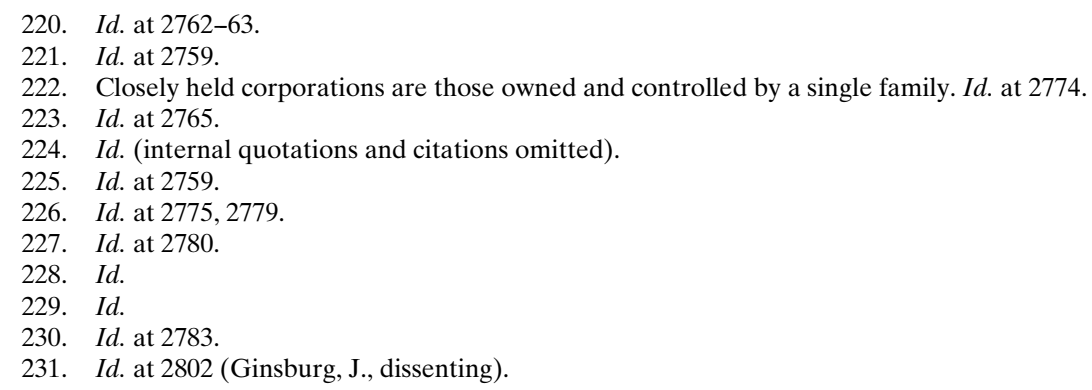


or according women equal pay for substantially similar work?"232 Justice Ginsburg questioned whether it ranked "as a less restrictive alternative to require the government to provide the money or benefit" that the employer has based his religious objection? ${ }^{233}$

Would the exemption...extend to employers with religiously grounded objections to blood transfusions (Jehovah's Witnesses); antidepressants (Scientologists); medications derived from pigs, including anesthesia, intravenous fluids, and pills coated with gelatin (certain Muslims, Jews, and Hindus); and vaccinations (Christian Scientists, among others)? $?^{234}$

Justice Ginsburg's strong dissent and her concern that "[t]he Court . . . has ventured into a minefield" clearly articulates Hobby Lobby's potential implications in health care and beyond. ${ }^{235}$ Hobby Lobby opens Pandora's Box because the holding can be read as broadly-not only for protecting religious beliefs of an individual, an employer, an institution, a corporation-but also inferring that religious claims of the sort that impose harms on others can and usually will trump any right to other services or goods such as accessible and affordable health care. The decision raises the question whether freedom to express and practice one's religious and moral beliefs can ever exert too great a burden on other individuals and society as a whole. ${ }^{236}$

Exceptionalism in health care extends well beyond the issue of employer-provided insurance, contraception, and the discrete issues addressed by Hobby Lobby and other related cases. The Supreme Court has never explicitly ruled on conscience clause legislation. However, the Court's decisions in cases such as Webster v. Reproductive Health Services $^{237}$ and Harris v. McRae ${ }^{238}$ problematically suggest that such laws are permissible because women do not have a guaranteed right to access abortion or other reproductive health services. ${ }^{239}$

232. Id. (citations omitted)

233. Id.

234. Id. at 2805.

235. Id.

236. In fact, Hobby Lobby is already being cited by courts granting exemptions to religious individuals and entities in contexts other than health care. Judge David Sam of the U.S. District Court of Utah cited Hobby Lobby in his decision holding that a member of the Fundamentalist Church of Jesus Christ of Latter-day Saints ("FLDS") is exempt from testifying in a child labor investigation because he had taken religious vows "not to discuss matters related to the internal affairs or organization" of his church and that to do so would "directly violat[e] [his] sincerely held religious beliefs." Perez v. Paragon Contractors, Corp., No. 2:13CV00281-DS, 2014 WL 4628572, at *3 (D. Utah Sept. 11, 2014) (internal quotation marks omitted); see also Denver Nicks, FLDS Successfully Cites Hobby Lobby Decision in Child Labor Suit, TIME (Sept. 16, 2014), http://time.com/3388117/flds-successfully-citeshobby-lobby-decision-in-child-labor-suit/.

237. 492 U.S. 490, 510 (1989).

238. 448 U.S. 297 (1980).

239. In Webster, the Court upheld a statutory ban on the use of public employees and facilities for non-therapeutic abortions, holding that "[n]othing in the Constitution requires States to enter or remain in the business of performing abortions." Webster, 492 U.S. at 510. In Harris, the Court held that the Hyde Amendment, which eliminated most Medicaid funding for abortions, did not create an unconstitutional obstacle for indigent women seeking abortions because it left them with "the same range of choice[s] . . . as [they] would have had if Congress had chosen to subsidize no health care 


\section{RELIGION AS A TOOL FOR DISCRIMINATION}

Thus far, this Article has challenged the legitimacy of religious rights claims made in the medical context. Specifically, it has made the normative argument that religion should not be used as a tool to inflict harm and injury on others. We do not doubt the sincerity of beliefs espoused by those who claim religious exemptions and exceptions. People can hold whatever religious views they want. Our point is that religion should not be a basis for harming others. A religious conviction whether strongly or sincerely held is neither a justification nor permission for discrimination.

In Part IV we argue that medical refusals and denials of medication dispensation in the reproductive contexts discriminate against and harm women in unique ways. Simply put, we argue there is no basis in ethics, law, or medicine for denying women reproductive medical care.

There are four main conflicts that arise when medical personnel act as both health care providers and state licensed religious objectors. First, patients' interests in their health may become subordinate to medical providers' desires to accommodate or promote religious interests. Second, medical providers' legal duties to comply with laws to accommodate patients may be perceived to conflict with state RFRA laws. Third, medical providers' ethical duties to at-risk female patients, including respecting their autonomy, providing efficacious care, avoiding malfeasance, and promoting social justice, are at odds with refusing care. Finally, medical personnel and institutional obligations secured by licensing to perform their trade in a given state may conflict with religious duties, thereby introducing religious norms into spaces where church and state should separate. Importantly, in addition to any conflicts of interest that may arise in these contexts, medical professionals' legal decisions may also be at odds with patients' constitutional rights.

As a normative matter, states should not enforce religious exemptions in the delivery of medicine, specifically reproductive healthcare. The substantial risks and undue burdens experienced by patients dictate that permitting religious exemptions in these contexts relegate women to a subordinate citizenship status. Essentially, women become second-class citizens, unable to acquire preventative medicines-sometimes even if their lives are at risk, as described earlier. Instantiated in medical providers denying women reproductive health services and requiring that they seek services elsewhere, are biases, stereotyping, and shaming. We find powerful analogies in the denial of accommodations to African Americans fifty years ago. Often, those who sought to exempt themselves from providing accommodations to African Americans claimed that those refused services could be accommodated elsewhere. Importantly, the criti-

costs at all." Harris, 448 U.S. at 317. A woman thus has the right to choose an abortion but does not necessarily have the right to the means to act on this choice-a woman's "freedom of choice ... does not confer an entitlement to such funds as may be necessary to realize all the advantages of that freedom." Id. at 317-18 (emphasis added). 
cal question here is not simply the matter of convenience argumentthat southern segregationists and lawmakers made to local courts fifty years ago-suggesting African Americans could be schooled, fed, clothed, and housed elsewhere.

As a matter of law, despite doctors, pharmacists, and others claiming a constitutional right to deny providing medical services to women who need them, we find nothing in the Constitution to support such claims. We believe the free exercise of religion is not a "free pass" for discrimination. Free exercise of religion does not create a legal right nor serves as a permissible justification to deny reproductive medical services. As has been stated elsewhere involving children, "[n]othing in the Constitution or statutes requires an exemption from state laws creating civil or criminal liability for parents who harm their children based on religion." ${ }^{240}$ We extend a similar analysis to this context.

\section{A. Statutory Claims}

Healthcare providers who deny medical services based on religion claim a right to do so. They argue that federal and state statutes as well as the Constitution protects their right to withhold medical services and deny the dispensation of medicines. Specifically, some point to state conscience statutes, which have been enacted in nearly all states and the District of Columbia. Medical providers claim that conscience clauses protect their right to withhold medical services that violate their religious beliefs. Indeed, some state constitutions offer more expansive protections than the First Amendment. ${ }^{241}$ Notwithstanding such protections, states equally have a duty to safeguard and protect their citizens' health.

\section{Pharmaceutical Context}

For example, in Noesen v. State Department of Licensing and Regulation, Mr. Noesen - a pharmacist-appealed an order affirming the Wisconsin Pharmacy Examining Board's decision reprimanding him and placing practice conditions on his license. In that case, "[ $t]$ he Board concluded Noesen violated the standard of care applicable to pharmacists when he refused to fill or transfer a patient's prescription for an oral contraceptive." ${ }^{242}$ Among other claims, Noesen asserted the reprimand violated his state constitutional right of conscience. He further argued that the Board "abused its discretion by instituting formal disciplinary proceedings instead of issuing an administrative warning." ${ }^{243}$ The Wisconsin Court of Appeals rejected these arguments and affirmed the Board's order.

240. Erwin Chemerinsky \& Michele Goodwin, Religion is Not a Basis for Harming Others, 104 GEO. L.J. 1111, 1128 (2016).

241. See Noesen v. State Dep’t Regulation \& Licensing, 2008 WI App 52, II 25, 311 Wis. 2d 237, 751 N.W.2d 385.

242. Id. II 1.

243. Id. 
Noesen also argued that the American Pharmacists Association's ("APhA") "Pharmacist Conscience Clause" provides safeguards for those who religiously object to dispensing certain medications. The APhA's conscience clause "recognizes the individual pharmacist's right to exercise conscientious refusal." ${ }^{444}$ This too, however, is a weak and untenable argument because Noesen failed to meet the APhA's standard, which emphasizes "patient's access to legally prescribed therapy." ${ }^{245}$ In this case, and in many others we described in Part II, pharmacists and doctors who claim religious exemptions and exceptions refuse to refer their patients to other care providers who will dispense medications and provide healthcare services. According to the court, Noesen "prevented all efforts Renz made to obtain her medication elsewhere when he refused to complete the transfer and gave her no options for obtaining her legally prescribed medication elsewhere." 246 Thus, Noesen departed not only from the standards of care imposed by the state, which granted his license, but by all other standards of care.

By refusing to dispense medications sought by women, pharmacists violate an expected standard of care ordinarily exercised by pharmacists. Quite simply, derogation of the standard of care harms patients. After all, what is the purpose of a licensing statute, but to promote and protect the public's health? As the court noted, "licensing statutes are enacted not for the benefit of the individuals licensed ...."247

Wisconsin's pharmacy licensing statute reads similarly to that in other states. It delineates unprofessional conduct as:

Engaging in any pharmacy practice which constitutes a danger to the health, welfare, or safety of patient or public, including but not limited to, practicing in a manner which substantially departs from the standard of care ordinarily exercised by a pharmacist which harmed or could have harmed a patient. ${ }^{248}$

We believe such statutes place pharmacists on notice of their responsibility to avoid inflicting harm on women patients. The law should not, and does not, need to enumerate each instance of potential breach, or what constitutes misconduct as doing so might be under inclusive or potentially over inclusive. And while pharmacists might challenge such laws as violating their religious rights, it is important to note that religious rights are subject to constraints - as a historical matter and as a matter of law as described in Part III. Licensing in any profession is not a right, but instead, a privilege and reserved for those willing to abide by rules of professional conduct, and anti-discrimination laws, and for those who perform their responsibilities dutifully and competently.

\footnotetext{
244. Id. II 17.

245. Id. 【 19.

246. Id. II 20.

247. Id. (citing Strigenz v. Dep’t Reg. \& Licensing Dentistry Examination Bd., 307 N.W.2d 664 (Wis. 1981))

248. WIS. AdMIN. CODE Phar § 10.03(2) (2012).
} 
For example, licensing statutes are rooted in the state's "police power to protect the public welfare and to safeguard the life, health, and property of its citizens." ${ }^{249}$ States have a compelling interest in protecting their citizens from harm. ${ }^{250}$ To test whether this interest is constitutional, courts will consider whether the states' interests can be served by a less restrictive alternative. In evaluating each case, courts will, and should, apply strict scrutiny. That is, "the burden cannot be generic but must be related to the exercise of a religious belief." ${ }^{251}$

Nevertheless, medical providers take issue with this legal standard, arguing that rarely are women actually harmed. They point to women who are denied their care and receiving services elsewhere and seize on the fact that pregnancies did not result in the wake of their denials of medications. ${ }^{252}$ They argue that women's risks of pregnancy due to missing a dosage of contraception is extremely low. However, pregnancy itself risks a woman's life. Pregnancies are fourteen times more likely to cause a woman's death than an abortion. ${ }^{253}$ Pregnancies may result in lifealtering conditions such as gestational diabetes, weight gain, high blood pressure, hypertension, and many other conditions, which reasonably a woman might take birth control to avoid..$^{254}$

\section{Abortion}

Women denied abortions at three private, nonprofit, nonsectarian hospitals brought an action against the hospitals to compel them to make their facilities available to women and their physicians for elective firsttrimester abortions. ${ }^{255}$ The plaintiffs made numerous constitutional claims, arguing that because these hospitals received federal, state, county, and municipal funds, their refusals to permit first trimester elective abortions constituted "state action," making federal constitutional protections applicable. ${ }^{256}$ They also made nonconstitutional claims, arguing that the hospitals were "quasi-public institutions" and were obligated to make their facilities available to the public. The hospitals violated this duty by establishing "arbitrary and unreasonable rules prohibiting elective abortions." ${ }^{257}$ The hospitals argued that they were private, nonprofit hospitals governed by boards of trustees and had the "absolute right" to

249. Noesen, 2008 WI App 52, II 15.

250. Indeed, we would argue that states have a duty to its citizens to avoid placing them in danger or at risk of medical injury. States breach this duty when and if they tolerate religiously based discrimination against certain citizens.

251. Noesen, 2008 WI App 52, II 25.

252. Id. II 21-22.

253. Serena Gorden, Abortion Safer for Women Than Childbirth, Study Claims, U.S. NEwS \& WORLD REP. (Jan. 23, 2012, 5:00 PM), http://health.usnews.com/health-news/family-health/womenshealth/articles/2012/01/23/abortion-safer-for-women-than-childbirth-study-claims.

254. See Maternal and Infant Health, CDC (Sept. 29, 2015), http://www.cdc.gov/reproductive health/maternalinfanthealth/pregcomplications.htm.

255. Doe v. Bridgeton Hosp. Ass'n, 366 A.2d 641, 641 (N.J. 1976).

256. Id. at 643 .

257. Id. 
determine who can use their facilities and whether to permit elective abortions. ${ }^{258}$

The trial court held the plaintiffs' constitutional claims invalid after concluding that no state action was involved. Instead, it focused on whether the hospitals' actions were "arbitrary and unreasonable in the sense that the adopted policy is so inimical to the public good that it must be set aside." 259 The trial court concluded that "moral and religious beliefs could reasonably justify the adoption of the regulations," giving the hospitals "just cause" for the regulations. ${ }^{260}$

The Supreme Court of New Jersey reversed, holding that private, nonprofit, nonsectarian hospitals, as "quasi-public institutions," cannot deny access to their facilities for elective abortions during the first trimester when the hospital has the necessary equipment, facilities, and capacities to perform such abortions and where they already permitted use of the equipment and facilities for therapeutic abortions. ${ }^{261}$ In its opinion, the court discussed the common law "innkeeper" principle, which requires innkeepers to "receive and lodge all comers in the absence of a reasonable ground of refusal." ${ }^{262}$ A refusal was reasonable only if it was related to the "inn's operation as an inn." 263 The court noted that although hospitals have discretion in managing and setting standards, they must not forget they operate for the public's benefit and that courts would "be remiss if they declined to intervene where ... the powers were invoked ... for a reason unrelated to sound hospital standards and not in furtherance of the common good." ${ }^{264}$ The court noted that neither the trial court nor the hospitals claimed the regulations at issue were adopted to further medical standards. ${ }^{265}$ In reaching its decision, the court explicitly stated that "[m]oral concepts cannot be the basis of a non-sectarian, non-profit eleemosynary hospital's regulations where that hospital is holding out the use of its facilities to the general public." ${ }^{266}$

While the case was pending appeal, New Jersey enacted its "conscience law" related to abortion and sterilization. ${ }^{267}$ The court agreed to consider the statute's viability in this case and concluded that interpreting the act to empower nonsectarian, nonprofit hospitals to refuse to provide elective abortions would constitute state action because of the well-settled federal constitutional right to an abortion during the first trimester established by Roe. ${ }^{268}$ A state's frustration of that right by its

258. Id.

259. Id. at 644 (internal citations omitted).

260. Id.

261. Id. at $641,647$.

262. Id. at 646 .

263. Id.

264. Id. (citing Greisman v. Newcomb Hosp., 192 A.2d 817, 825 (N.J. 1963)).

265. Id. at 647 .

266. Id. The court did, however, state that its decision did not mean that religious/moral beliefs are necessarily inappropriate grounds for a hospital operated by a recognized religious body to prohibit elective abortions. Its decision only applies to non-sectarian hospitals. Id.

267. Id.

268. Id. 
action would thus violate this constitutional guarantee and the court, therefore, concluded that New Jersey's conscience law did not apply to nonsectarian, nonprofit hospitals like the defendant hospitals in this case. ${ }^{269}$

Finally, why should healthcare providers' discriminatory religious views acquire legal legitimacy and authority in the denial of women's reproductive related healthcare services, including when a patient's life is at risk? Would such discrimination be tolerated based on race? Likely not, even though racial prejudices emerge in the medical setting. In 2013, the Hurley Medical Center in Flint, Michigan, accommodated a request made by a parent that no African Americans tend to his newborn. ${ }^{270}$ The father, who allegedly brandished a swastika tattoo, alerted a nurse that African Americans were not to touch or care for his baby. To comply with the father's request, hospital officials removed Nurse Tonya Battle (an African American), from care of the child in the Neonatal Intensive Care Unit ("NICU") and reassigned a white nurse. ${ }^{271}$ Allegedly, the nurse manager claimed in a meeting that she could sympathize with the father, "comparing it to a German caring for a Jew." ${ }^{272}$ According to Battle's lawsuit, hospital staff posted a note next to the baby's name on the assignment clipboard: "NO AFRICAN AMERICAN NURSE TO TAKE CARE $O F B A B Y . " 273$

In that case, the Equal Opportunity Commission investigated, found wrongful discrimination, and settled the lawsuit, negotiating a financial settlement for the African American nurse and establishing a five-year monitoring protocol and training for hospital employees. ${ }^{274}$ Even so, what distinguishes that case from those we discuss in Part II is that these women were all denied care. Unlike the father who desired only whites to care for his child and was accommodated, these women sought medications and treatment and were all refused. Nevertheless, could the hospital have avoided a finding of wrongful action if they claimed their actions were motivated by sincerely held religious beliefs and that they were exempt from complying with civil rights laws?

Granting healthcare providers the authority to discriminate based on religion politicizes their roles and creates negative societal, legal, and medical impacts. In this context, physicians, nurses, and religious institu-

269. Id.

270. Robin Erb, Nurse Sues After Hospital Grants Dad's Racial Request, U.S.A. ToDAY (Feb. 18 , 2013, 8:12 PM), http://www.usatoday.com/story/news/nation/2013/02/18/black-nurse-lawsuit-fatherrequest-granted/1928253/.

271. Id.

272. Katie Couric, A Shocking Case of Racial Discrimination in a Hospital, YouTuBE (Mar. 6, 2013), https://www.youtube.com/watch?v=cwt1931JyHM.

273. Erb, supra note 270 (emphasis added). Such instances of using racial preferences in the medical setting raise questions about the permissibility of such practices-not only as a legal matter, but also as matters of health and bioethics. See generally Kimani Paul-Emile, Patients' Racial Preferences and the Medical Culture of Accommodation, 60 UCLA L. REV. 462 (2012).

274. See Gary Ridley, Hurley Settles Race Discrimination Complaint That Claimed Black Nurses Were Banned from Treating White Baby in Flint, M LIVE (Sept. 27, 2013, 10:44 AM), http://www. mlive.com/news/flint/index.ssf/2013/09/hurley_settles_race_discrimina.html\#incart_story_package. 
tions wear two hats: that of health care providers and state-licensed entities entitled to discriminate.

\section{B. The Hobby Lobby Problem}

Does an individual's religious belief exempt her from complying with valid state laws in areas where the state is free to regulate? Despite its ruling in Hobby Lobby, which addressed a federal statute, the U.S. Supreme Court has "never held that an individual's religious beliefs excuse him from compliance with an otherwise valid law prohibiting conduct that the State is free to regulate." 275

Nevertheless, the Court's ruling in Hobby Lobby expanded federal protection of religious freedom of "person[s]" to for-profit corporations and their owners, introducing a precarious precedent, namely that "closely held" for-profit corporations whose business purposes notably exclude religion, nonetheless may claim religious exemptions from complying with federal laws that seeks to grant rights or secure the interests of protected classes. ${ }^{276}$

Importantly, this problematic precedent extends beyond reproductive liberty and isolated corporations owned by devout religious believers for three key reasons. First, the ruling grants exemption to all "closelyheld" corporations in the U.S. without limitations. ${ }^{277}$ Second, in granting such broad deference, the Court arbitrarily singles out reproductive healthcare protection to women as a subordinate or inferior right, emphasizing " $[\mathrm{t}]$ his decision concerns only the contraceptive mandate and should not be understood to hold that all insurance-coverage mandates, (e.g., for vaccinations or blood transfusions) must necessarily fall if they conflict with and employer's religious beliefs." ${ }^{278}$ Third, the Hobby Lobby ruling extends beyond what could be perceived as the "isolated" reach of Hobby Lobby's female employees to all women employed at "closelyheld" corporations. As reported by the Washington Post, fifty-two percent of Americans are employed by closely-held corporations. ${ }^{279}$

For example, the overwhelming majority of U.S. corporations incorporate as "closely held" businesses. ${ }^{280}$ Hobby Lobby is incorporated as a non-income tax paying "S Corporation," 281 similar to several million

275. Peace Lutheran Church \& Acad. v. Vill. of Sussex, 2011 WI App 139, \I 20, 246 Wis. 2d 502, 631 N.W.2d 229 (citation omitted).

276. Burwell v. Hobby Lobby, 134 S. Ct. 2751, 2755 (2014)

277. The Court failed to specify what constitutes a "closely held" corporation for purposes of its analysis. For example, Justice Alito omitted any specifications defining how many stakeholders a company must have to qualify under RFRA to bring a claim. Id. at 2774 .

278. Id. at 2758 .

279. Aaron Blake, A LOT of People Could be Affected by the Supreme Court's Birth Control Decision-Theoretically, WASH. POST (June 30, 2014), http://www.washingtonpost.com/blogs/the-fix/ wp/2014/06/30/a-lot-of-people-could-be-affected-by-the-supreme-courts-birth-control-decision/.

280. Morten Bennedsen \& Daniel Wolfenzon, The Balance of Power in Closely Held Corporations, 58 J. FIN. ECON. 113, 114 (2000).

281. According to the Pew Research Center, S corporations "cannot have more than 100 shareholders (although all members of the same family are treated as a single shareholder)." Drew DeSil- 
U.S. corporations. ${ }^{282}$ According to the Pew Research Center, in 2011, "there were 4,158,572 S corporations" 283 doing business in the U.S. In an oft-cited research study published in 2000, The Balance of Power in Closely Held Corporations, ${ }^{284}$ economics professors Morten Bennedsen and Daniel Wolfenzon point out that less than one quarter of one percent of U.S. corporations were publicly held. ${ }^{285}$

Justice Alito's implied reasoning that the Court's holding is narrow because Hobby Lobby and the other litigating parties are "owned and controlled by members of a single family," 286 potentially misinforms and obscures the more profound fact that closely-held corporations dominate the U.S. employment landscape. They employ more than twenty-nine million Americans. ${ }^{287}$ In fact, over ninety-nine percent of S corporations have ten or fewer shareholders ${ }^{288}$ - the majority of which are family members.

Justice Alito opined that to rule against Hobby Lobby would essentially victimize such entities, but the majority's lengthy opinion failed to offer a rigorous analysis answering why. ${ }^{289}$ The majority offered an unpersuasive illustration of the harms that Hobby Lobby might endure, such as "giv[ing] up the right to seek judicial protection of their religious liberty or forgo[ing] the benefits of operating as [a] corporation[]." ${ }^{290} \mathrm{Nei}-$ ther seemed plausible in light of the fact that private, for-profit corporations never possessed a right to discriminate in such form, and providing contraception to employees had not forced the company to close as it already provided vasectomy coverage for its male employees, ${ }^{291}$ thereby raising equal protection concerns.

The Court's ruling in Hobby Lobby is problematic for reasons addressed herein, not the least of which is the potential reach of the decision and the profound harms that result as a matter of this case and those to come. We address this dynamic as "exceptionalism," which on insufficiently interrogated grounds grants authority to individuals and institutions to violate the constitutionally protected interests of pregnant women and women seeking reproductive health-care services, including contraception and abortion.

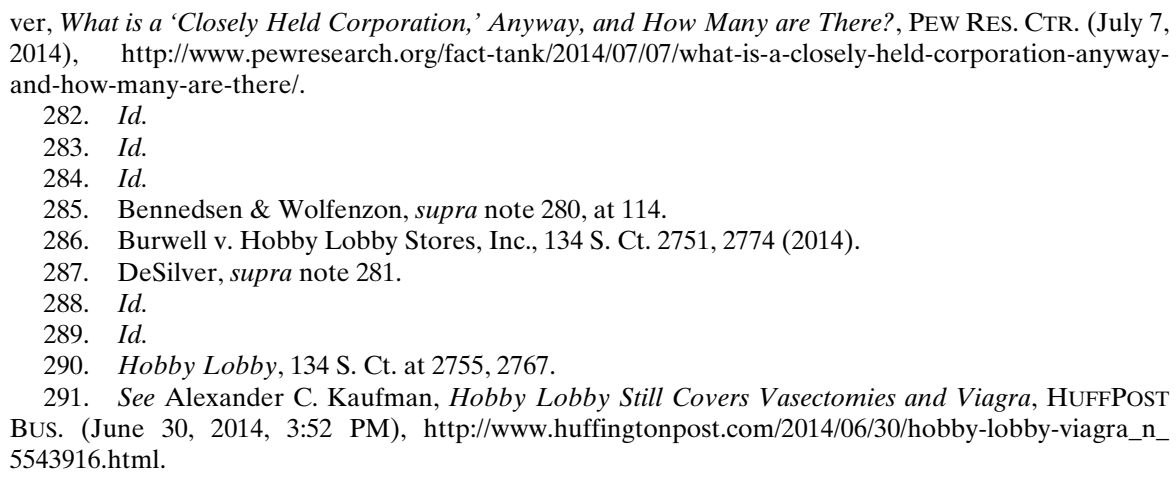

291. See Alexander C. Kaufman, Hobby Lobby Still Covers Vasectomies and Viagra, HuFFPost Bus. (June 30, 2014, 3:52 PM), http://www.huffingtonpost.com/2014/06/30/hobby-lobby-viagra_n_ 5543916.html. 


\section{CONCLUSION}

In this Article, we employed the term "exceptionalism" to characterize a misperception in law that "religiously based rights" trump all other constitutionally derived interests based on the principle that religious freedom is extraordinarily unique and vitally different from all other rights for which law must grant its protection. Religious exceptionalism suggests two important, but problematic ideas, which we reject.

First, religious exceptionalism casts a hierarchy within law and establishes the ordering of legal rights. In other words, proponents of religious exceptionalism perceive its hierarchy to other fundamental rights and liberty interests. Second, as a result, religiously based rights and individuals protected by such interests need not conform to general principles, normal rules, or non-discriminatory practices. For example, arguments advancing closely held religious beliefs can be deployed not only as mighty swords, but also as legitimate means of discriminating against protected classes. To this end, constitutional rights extend beyond legitimately protecting religious minorities from state and institutional tyranny, but grants priority in a ranking of rights, and permits even cruel discrimination in the advancement of religious rights. We have argued that religious exceptionalism misreads the Constitution and establishes problematic norms. 
